\title{
Review Article \\ Disinfection of Needleless Connector Hubs: Clinical Evidence Systematic Review
}

\author{
Nancy L. Moureau ${ }^{1,2,3}$ and Julie Flynn ${ }^{3,4}$ \\ ${ }^{1}$ PICC Excellence, Inc., Online Education, Hartwell, GA 30643, USA \\ ${ }^{2}$ Greenville Hospital System, Greenville, SC 29605, USA \\ ${ }^{3}$ Alliance for Vascular Access Teaching and Research (AVATAR group) Griffith University, Nathan, Brisbane, QLD 4111, Australia \\ ${ }^{4}$ Royal Brisbane \& Women's Hospital, Brisbane, QLD 4029, Australia
}

Correspondence should be addressed to Nancy L. Moureau; nancy@piccexcellence.com

Received 12 November 2014; Accepted 19 February 2015

Academic Editor: Claire M. Rickard

Copyright (C) 2015 N. L. Moureau and J. Flynn. This is an open access article distributed under the Creative Commons Attribution License, which permits unrestricted use, distribution, and reproduction in any medium, provided the original work is properly cited.

Background. Needleless connectors (NC) are used on virtually all intravascular devices, providing an easy access point for infusion connection. Colonization of NC is considered the cause of $50 \%$ of postinsertion catheter-related infections. Breaks in aseptic technique, from failure to disinfect, result in contamination and subsequent biofilm formation within $\mathrm{NC}$ and catheters increasing the potential for infection of central and peripheral catheters. Methods. This systematic review evaluated 140 studies and 34 abstracts on NC disinfection practices, the impact of hub contamination on infection, and measures of education and compliance. Results. The greatest risk for contamination of the catheter after insertion is the NC with $33-45 \%$ contaminated, and compliance with disinfection as low as $10 \%$. The optimal technique or disinfection time has not been identified, although scrubbing with $70 \%$ alcohol for 5-60 seconds is recommended. Studies have reported statistically significant results in infection reduction when passive alcohol disinfection caps are used (48-86\% reduction). Clinical Implications. It is critical for healthcare facilities and clinicians to take responsibility for compliance with basic principles of asepsis compliance, to involve frontline staff in strategies, to facilitate education that promotes understanding of the consequences of failure, and to comply with the standard of care for hub disinfection.

\section{Background}

Intravenous catheters and those related devices used to gain access to the veins for the purpose of infusing medications or solutions have evolved significantly over the past three decades. One of the more noticeable changes involves the way intravenous devices are accessed. Early concerns over needle safety for healthcare workers led to the creation of products that provide needle-free access. While these products did eliminate the risk of accidental needle injury for the clinician, some needleless products raised new issues for the patient; namely, a noted increase in the occurrence of catheter associated bloodstream infections (CABSI) and central line associated bloodstream infections (CLABSI) [13]. Risk factors for infection include poor adherence to aseptic technique, needleless connector (NC) design variations, and inconsistent health care staff education and training
[1-3]. NC are used on virtually all intravascular devices in the USA; they provide an easy access point for syringe or tubing attachment and have now become the central access point for all connections. Yet, despite providing some level of safety, concerns over infection related to NC contamination exist. Surface design, gaps around valve closure surface, segmented fluid pathway with dead space, differing internal mechanisms, clear or obscured visibility, variable blood reflux, clamping sequences, and different flushing instructions, depending on the type of $\mathrm{NC}$, all play a part in the level of risk associated with the device. Before the advent of NC, clinicians had an intuitive understanding that prior to penetrating the septum with the needle the septum required disinfection. Current surface disinfection of NC is not necessarily intuitive. Initially, needleless split septum access points used a blunt "needle-looking" type cannula. As a result, the disinfection process remained intuitive. Split 
septum access devices continue to be recommended as a lower risk option for needleless connection; however, they have lost popularity because they require multiple parts and pieces for access and allow direct needle access through the septum/diaphragm leading many facilities to switch to luer access devices. With the changes to the access point using direct luer connection through the NC, the intuitive sense to disinfect the surface prior to access is lost; many clinicians fail to realize the consequences of this breech in aseptic technique [4-6]. Colonization of catheter hubs and NC, with subsequent bacterial ingress into the catheter lumen, is considered the cause of $50 \%$ of postinsertion catheter-related infections [3-7]. Disinfection of the exposed surface of the $\mathrm{NC}$ is necessary to avoid contamination and subsequent intraluminal biofilm formation and protect patients from infection.

Vast improvements have been made in the reduction of CLABSIs attributed to insertion procedures. The results of the groundbreaking Keystone initiative demonstrated the effect of five measures, known as the Central Line Bundle, on the improvement of outcomes during insertion of central venous catheters [64, 105]. Consistent application of the bundle, with compliance verified during the insertion procedure (checklist), has reduced insertion related CLABSI by more than $44 \%$ in the USA [52]. However, despite the successes of the insertion bundle, full compliance more than seven years later is still lacking, with reported compliance rates at one institution ranging from $0.0 \%$ at the beginning of the intervention to $37.1 \%(139 / 375)$, according to the Jeong study, with similar results in other institutions $[65,66,106,107]$. Even in institution where full compliance of the bundle exists, CLABSIs are still occurring [108]. Disinfection of the NC access site was not included in the insertion related central line bundle. The goal of any effective infection prevention program is zero CLABSIs. To reach the goal of zero, consideration must be given for the pathogenesis of catheter related infections and an investigation into current human factors of catheter management preventing achievement of this goal.

While many experts agree that application of the insertion bundle is one of the best ways to prevent insertion-related infection, the bundle does not address NC, aseptic access, or any postinsertion catheter usage issues. A Pennsylvania study reported that $71.7 \%$ (468/653) of central line infections occurred five days or more after insertion and may have been directly related to use and care of intravascular devices $[60,108-110]$. Contamination of the catheter directly through the catheter hub has been confirmed through published studies [12, 13, 111-113]. These studies found that bacteria identified on external hub surfaces were also present in biofilm sampled from random locations within the needless connector. Research performed at one institution revealed that patient skin flora was not the source of catheter related bloodstream infections in any of their cases; all infections in this study originated from the catheter hub $[6,113]$. Infections later in the life of the catheter develop from improper catheter manipulation, failure to perform hand hygiene, inadequate time to clean $\mathrm{NC}$, inadequate training, and poor access and exit site management $[2,67,110,112]$. Disinfection of a catheter hub prior to flushing or prior to the administration of medications is required for all aseptic access, yet in the Karchmer study, 31\% of clinicians did not even attempt to disinfect, even when under active observation $[1,64$, $88,114]$. In a study by Lee the disinfection compliance by clinicians prior to NC access was measured at only $10 \%$ [115]. This common break in aseptic technique sets the stage for biofilm formation within NC and catheters and increases the potential for delayed infection of both central and peripheral catheters $[14,60,68,112,116]$. The results of the Pennsylvania Patient Safety Advisory Report and independent biofilm sampling of NC suggest that more attention is needed for aseptic access and maintenance practices [109].

\section{What Is Disinfection?}

According to the Epic3 Evidence-Based Guidelines for Preventing Healthcare Infections, disinfection is defined as the use of chemical or physical methods to reduce the number of pathogenic microorganisms on surfaces to a level at which they are not able to cause harm, but which does not usually destroy spores [53]. These guidelines further state that disinfection methods used in combination with cleaning blood or other debris off the surface as disinfectants have limited ability to penetrate organic material [8]. The Association for Professionals in Infection Control (APIC) defines disinfection as a process to eliminate microorganisms accomplished with the use of liquid chemicals or pasteurizing; process works best by having proper contact time and dilution of disinfection agent [117]. Recommendations from the Centers for Disease Control [8], the Agency for Healthcare Research and Quality [9], the Society for Healthcare Epidemiology of America [10], and the Infusion Nurses Society $[11,118]$ state that NC should be consistently and thoroughly disinfected using mechanical friction with $70 \%$ alcohol, alcoholic chlorhexidine, or povidone iodine prior to each access of an intravascular device and listed in evidence as a Category $1 \mathrm{~A}$.

2.1. Goal. The goal of this review is to assess current literature related to disinfection of NC to establish recommendations that promote aseptic access, reducing infection risk for the patient.

2.2. Search Methodology. The purpose of this systematic review was to evaluate the supporting evidence for disinfection practices of NC, catheter hub, stopcock, and side ports that reduce the transfer of microorganisms through intravascular device access. This report is based on an electronic systematic literature search and review of published materials from Pubmed, Medline, Scopus, Ovid, jStor, CINAHL, Cochrane, Athens, and ScienceDirect by crossreferencing these key terms for years 1977-December 2014. High level evidence from RCTs that tested "cause and effect" relationships between different disinfection approaches for NC and patient infection was initially sought. Since no RCTs were found, lower level evidence including clinical and in vitro (laboratory) studies was reviewed, as long as these included reporting of quantitative data. Broad $\mathrm{MeSH}$ search 
term "disinfection" and "needleless connector" combinations were used with additional keywords listed below:

(i) disinfection, antiseptic, alcohol, chlorhexidine, and anti-infective agents,

(ii) intravenous, intravascular, and vascular access,

(iii) hub, catheter hub, scrub the hub,

(iv) intravenous connector, NC, luer activated device, and mechanical valve,

(v) aseptic practices, contamination, and compliance,

(vi) education, staff education, and medical education,

(vii) infection, infection prevention, catheter related infections, CLABSI, bloodstream infections, bacteremia, sepsis, and cross-infection,

(viii) catheter maintenance and line care,

(ix) insertion and bundle,

(x) intravenous technology,

(xi) catheter cap, access port, disinfecting cap, antimicrobial cap, hub protection cap, and port protector,

(xii) Infection prevention guidelines and recommendations.

Additional studies were cross-referenced through manual search. Conference posters and abstracts were included in the review. Manufacturers websites of disinfection ports and two manufacturers (Excelsior Medical, Neptune, NJ; Ivera Medical Corporation, San Diego, CA) were contacted directly requesting all published materials and posters on disinfection products. There were no identified formal published systematic reviews of the effectiveness of NC disinfection practices, indicating a knowledge gap in this area. Search results were evaluated by title, abstract, and content. Selected papers were subjected to full-text assessment. Initial selection process and critique was performed by one researcher (NM), with evidence rating performed by two researchers independently (NM and JF), with any disagreement in quality rating resolved by discussion.

2.3. Inclusion/Exclusion Criteria. Criteria checklist for inclusion was any NC disinfection publications and abstracts that fit subcategories for disinfection, hub contamination/infection prevention, education/compliance, surveys, and guidelines/recommendations for disinfection. Inclusion criteria consisted of publications meeting search terms and topic requirements under sub groupings:

(1) disinfection agents used on intravascular device surfaces including studies and reviews of NC and infection prevention,

(2) sources of contamination through intravascular devices,

(3) education and compliance for infection prevention,

(4) guidelines and recommendations for infection prevention with disinfection.

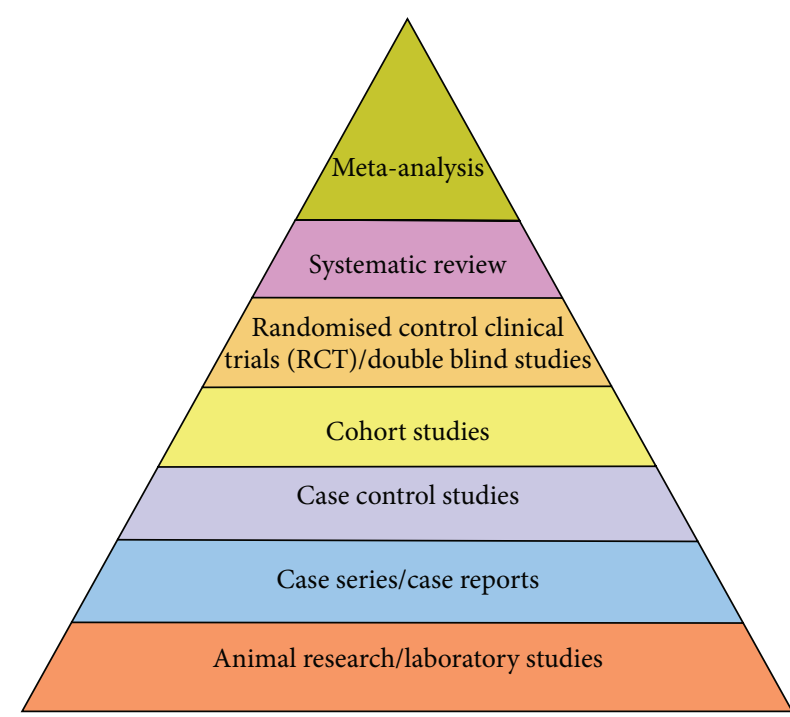

FIGURE 1

Exclusion criteria were

(i) nonresearch papers,

(ii) studies of adult, pediatric, or neonatal increasingly important role patients not inclusive of intravascular device disinfection practices,

(iii) primary populations outside acute care,

(iv) publications not translated into English,

(v) studies prior to 1984 .

\section{Results}

The systematic review of these topics yielded a total of 433 papers and abstracts. After initial review 259 articles did not meet eligibility requirements and were removed. Included studies consisted of 140 publications dealing with disinfection/catheter hub/NC contamination with 34 abstracts/posters. Of the studies 67 were graded according to the strength of the study. The study results and ratings of the literature are included in Tables 1-5 and Figure 1, with recommendations are represented in Table 6.

3.1. Why Disinfect? A catheter is inserted into a vein or artery to provide a pathway for the administration of medications or solutions necessary to improve a patient's health or condition. Because catheters provide an open conduit into the vasculature, a NC is attached, via luer threaded connection, to the integrated hub end of the catheter establishing a closed system. Studies reflecting benefits of closed systems with NC have trended toward demonstration of protection for catheter and hub colonization $[4,119]$. In a prospective controlled study by Rosenthal and Maki and multicenter prospective cohort by Rangel-Frausto et al., open systems compared to closed systems resulted in major reductions in catheter related infections [120]. NC used as a closed system 
TABLE 1: Disinfecting agents and devices literature.

\begin{tabular}{|c|c|}
\hline & Grade $^{*}$ \\
\hline (1) J. Bak et al., Photochem Photobio, vol. 87, pp. 1123-1128, 2011. & $\mathrm{D}$ \\
\hline (2) J. Bak and T. Begovic, J Hosp Infect, vol. 84, pp. 173-177, 2013. & $\mathrm{D}$ \\
\hline (3) J. D. Brown, H. A. Moss, and T. S. Elliott, J Hosp Infection, vol. 36, pp. 181-189, 1997. & $\mathrm{D}$ \\
\hline (4) A. L. Buchman, J. Spapperi, and P. Leopold, J Vasc Access, vol. 10, no. 1, pp. 11-21, 2009. & $\mathrm{D}$ \\
\hline (5) A. L. Casey et al., J Hosp Inf, vol. 54, no. 4, pp. 288-293, 2003. & $\mathrm{~B}$ \\
\hline (6) C. Chernecky, L. Casella, E. Jarvis et al., J Research Nsg, vol. 15, no. 5, pp. 405-415, 2010. & $\mathrm{D}$ \\
\hline (7) M. DeVries, P. S. Mancos, and M. J. Valentine, J Assoc Vasc Access, vol. 19, no. 2, pp. 87-93, 2014. & $\mathrm{C}$ \\
\hline (8) K. Field, C. McFarlane et al., Infect Control Hosp Epidemiol, vol. 28, no. 5, pp. 610-613, 2007. & $\mathrm{C}$ \\
\hline $\begin{array}{l}\text { (9) P. Gould and A. Oudakker, "Getting to ZERO central line associated bloodstream infections," Poster AVA, } \\
\text { National Harbour, M.d., USA, September } 2010 .\end{array}$ & $\mathrm{C}$ \\
\hline (10) K. Guerin, J. Wagner, K. Rains, and M. Bessesen, Am J Infect Control, vol. 38, no. 6, pp. 430-433, 2010. & $\mathrm{C}$ \\
\hline (11) J. L. Holroyd, D. A. Paulus et al., Anesth Analg, vol. 118, no. 2, pp. 333-343, 2010. & $\mathrm{D}$ \\
\hline (12) H. Hong, D. F. Morrow, T. J. Sandora, and G. P. Priebe, Am J Infect Control, vol. 41, no. 8, pp. e77-e79, 2013. & $\mathrm{D}$ \\
\hline (13) W. Kaler and R. Chinn, JAVA, vol. 12, no. 3, pp. 140-147, 2007. & $\mathrm{D}$ \\
\hline $\begin{array}{l}\text { (14) J. P. Kennedy, R. A. Lasher, D. Solomon, and R. W. Hitchcock, J Medical Devices, vol. 4, no. 2, Article ID } \\
027509,2010 .\end{array}$ & $\mathrm{D}$ \\
\hline (15) C. Leon, F. Alvarez-Lerma, S. Ruiz-Santana et al., Crit Care Med, vol. 31, no. 5, pp. 1318-1324, 2003. & $\mathrm{D}$ \\
\hline (16) M. Leone and L. Dillon, J Infusion Nsg, vol. 31, no. 2, pp. 84-91, 2008. & $\mathrm{C}$ \\
\hline (17) M. Leone and M. Pratt, Infusion, pp. 10-13, Nov/Dec 2011. & $\mathrm{D}$ \\
\hline (18) J. L. Lockman, E. S. Heitmiller, J. A. Ascenzi, and I. Berkowitz, Anesth, vol. 114, p. 958, 2011. & $\mathrm{D}$ \\
\hline (19) R. W. Loftus et al., Anesthesia, vol. 115, no. 5, pp. 1109-1118, 2012. & $\mathrm{D}$ \\
\hline (20) J. Luna, G. Masdeu et al., Eur J Clin Micro Infect Dis, vol. 19, pp. 655-662, 2000. & C-D \\
\hline (21) J. Macias et al., Am J Infect Control, vol. 31, pp. 634-637, 2013. & $\mathrm{D}$ \\
\hline (22) D. G. Maki, Clinical Infectious Diseases, vol. 50, no. 12, pp. 1580-1587, 2010. & $\mathrm{D}$ \\
\hline (23) M. Mazher et al., Letters in Applied Microbiology, vol. 57, no. 4, pp. 282-287, 2013. & $\mathrm{D}$ \\
\hline (24) S. Z. Menyhay and D. G. Maki, Infect Control Hosp Epidemiol, vol. 27, no. 1, pp. 23-27, 2006. & $\mathrm{D}$ \\
\hline (25) S. Z. Menyhay and D. G. Maki, Am J Infect Control, vol. 36, no. 10, pp. S174.e171-S174.e175, 2008. & $\mathrm{D}$ \\
\hline (26) K. C. Merrill et al., Am J Infect Control, vol. 42, no. 12, pp. 1274-1277, 2014. & $\mathrm{~B}-\mathrm{C}$ \\
\hline (27) M. K. Muffly et al., Am J Infect Control, vol. 38, no. 9, pp. 734-739, 2010. & $\mathrm{D}$ \\
\hline $\begin{array}{l}\text { (28) J. Oto, H. Imanaka, M. Konno, E. Nakataki, and M. Nishimura, Am J Infect Control, vol. 39, no. 4, pp. 309-313, } \\
\text { 2011. }\end{array}$ & $\mathrm{B}-\mathrm{C}$ \\
\hline (29) E. Perez et al., Journal of Clinical Microbiology, vol. 52, no. 3, pp. 823-831, 2014. & $\mathrm{~B}-\mathrm{C}$ \\
\hline (30) C. Ramirez, A. Lee, and K. Welch, JAVA, vol. 17, no. 4, pp. 210-213, 2014. & $\mathrm{~B}-\mathrm{C}$ \\
\hline (31) M. E. Rupp, S. Yu, T. Huerta et al., Infect Control Hosp Epidemiol, vol. 33, no. 7, pp. 661-665, 2012. & $\mathrm{C}$ \\
\hline (32) K. L. Ruschman and J. S. Fulton, J Intraven Nurs, vol. 16, no. 5, pp. 304-308, 1993. & $\mathrm{D}$ \\
\hline (33) C. Salgado et al., Infect Control Hosp Epidemiol, vol. 28, no. 6, pp. 684-688, 2007. & $\mathrm{C}$ \\
\hline (34) M. Salzman, H. Isenberg, and L. Rubin, J Clin Microbiol, vol. 31, no. 3, pp. 475-479, 1993. & $\mathrm{D}$ \\
\hline (35) S. Sannoh et al., Am J Infect Control, vol. 38, no. 6, pp. 424-429, 2010. & $\mathrm{C}$ \\
\hline (36) M. Segura, F. Alvarez-Lerma, J. M. Tellado et al., Ann Surg, vol. 223, no. 4, pp. 363-369, 1996. & $\mathrm{D}$ \\
\hline (37) S. Simmons, C. Bryson, and S. Porter, Critical Care Nursing Quarterly, vol. 34, no. 1, pp. 31-35, 2011. & $\mathrm{D}$ \\
\hline (38) J. Smith, G. Irwin, M. Viney et al., J Assoc Vasc Access, vol. 17, no. 3, 2012. & $\mathrm{D}$ \\
\hline $\begin{array}{l}\text { (39) J. S. Soothill, K. Bravery, A. Ho, S. Macqueen, J. Collins, and P. Lock, Am J Infect Control, vol. 37, no. 8, pp. } \\
\text { 626-630, } 2009 .\end{array}$ & $\mathrm{C}$ \\
\hline (40) C. Stango, D. Runyon, J. Stern, I. Macri, and M. Vacca, JIN, vol. 37, no. 6, pp. 1-4, 2014. & $\mathrm{C}$ \\
\hline $\begin{array}{l}\text { (41) M. A. Sweet, A. Cumpston, F. Briggs, M. Craig, and M. Hamadani, Am J Infect Control, vol. 40, no. 10, pp. } \\
\text { 931-934, } 2012 .\end{array}$ & C-B \\
\hline (42) M. Wright, J. Tropp, D. Schora et al., Am J Infect Control, vol. 41, no. 1, pp. 33-38, 2012. & $\mathrm{C}-\mathrm{B}$ \\
\hline (43) J. C. Yebenes, M. Delgado, G. Sauca et al., Crit Care Med, vol. 36, no. 9, pp. 2558-2561, 2008. & $\mathrm{D}$ \\
\hline
\end{tabular}

${ }^{*}$ Grade of recommendation was modified from the NHMRC definitions (NHMRC, 2009) [102]. To achieve a grade of A the research is required to be a high quality randomized control trial (RCT) or a systematic review of high quality RCTs. Laboratory (in vitro) research was classified as level V evidence (DeVries and Berlet, 2010 [103]; The University of Newcastle Australia, 2014 [104]).

A: body of evidence can be trusted to guide practice, systematic review or RCT.

B: body of evidence can be trusted to guide practice in most situations, RCT or high quality observational study.

C: body of evidence provides some support for recommendation but care should be taken in its application, observational studies.

D: Level V evidence or evidence that is weak and recommendation must be applied with caution, expert opinion, animal or laboratory studies. 
TABLE 2: Needleless connector literature.

(1) E. Bouza et al., J Hosp Infect, vol.54, no. 4, pp. 279-287, 2003.

(2) B. Caillouet, J Assoc Vasc Access, vol.17, no. 2, pp. 86-89, 2012.

(3) D. Cain and G. Jones, "Comparison of catheter occlusions between a mechanical valve injection cap and positive displacement injection cap," Poster NHIA, Dallas, Tex, USA, April 12-15, 2010.

(4) A. L. Casey, S. Burnell et al., J Hosp Infect, vol. 65, no. 3, pp. 212-218, 2007.

(5) A. L. Casey, T. Worthington, P. A. Lambert, D. Quinn, M. H. Faroqui, and T. S. Elliott, J Hosp Infect, vol. 54, no. 4, pp. 288-293, 2003.

(6) C. Chernecky and J. Waller, J Adv Nsg, vol. 67, no. 7, pp. 1601-1613, 2011.

(7) C. C. Chernecky, D. Macklin, W. R. Jarvis, and T. V. Joshua, AJIC, vol. 42, no. 2, pp. 200-202, 2014.

(8) S. Cicalini, F. Palmieri, and N. Petrosillo, Critcal Care, vol. 8, pp. 157-162, 2004.

(9) J. M. Costello, D. F. Morrow et al., Pediatrics, vol. 121, pp. 915-923, 2008.

(10) ECRI Institute, “Evaluation: needleless connectors," Health Devices, vol. 37, no. 9, pp. 261-281, 2008.

(11) C. E. Edmiston, V. Markina, AJIC, vol. 38, pp. 421-423, 2010.

(12) F. Esteve, M. Pujol, E. Limon et al., Journal of Hospital Infection, vol. 67, no. 1, pp. 30-34, 2007.

(13) Hadaway L., J Assoc Vasc Access, vol. 16, no. 1, pp. 20-33, 2011.

(14) M. Ishizuka, H. Nagata, K. Takagi, and K. Kubota, Int Surg, vol. 98, pp. 88-93, 2013.

(15) W. Jarvis, C. Murphy, K. Hall et al., Clin Infect Dis, vol. 49, no. 12, pp. 1821-1827, 2009.

(16) N. Khalidi, D. S. Sovacevich, L. F. Papke-O’Donnell, and I. Btaiche, J Assoc Vasc Access, vol 14, no. 2, pp. 84-91, 2009.

(17) B. S. Niël-Weise, T. J. Daha, P. J. van den Broek, J Hosp Infect, vol. 62, no. 4, pp. 406-13, 2006.

(18) C. Salgado, L. Chinnes, T. Paczesny, and J. Cantey, Infect Control Hosp Epidemiol, vol. 28, no. 6, pp. 684-688, 2007.

(19) S. Schilling, D. Doellman, N. Hutchinson, and B. R. Jacobs, J Paren Ent Nut, vol. 30, no. 2, pp. 85-90, 2006.

(20) R. J. Sherertz, T. B. Karchmer, E. Palavecino, and W. Bischoff, European J Clin Micro Infect Dis, vol. 30, no. 12, pp. 1571-1577, 2011.

(21) L. Steininger, "In search of zero: eight years of interventions lead to reduced central line associated bloodstream infection rates," Poster 5th Decennial International Conference on Healthcare-Associated Infections, Organized by SHEA, CDC, APIC, and IDSA, Atlanta, Ga, USA, March 2010.

(22) Y. P. Tabak, W. R. Jarvis, X. Sun, C. T. Crosby, and R. S. Johannes, Am J Infect Control, vol. 42, no. 12, pp. 1278-1284, 2014.

(23) J. C. Yébenes, R. Martínez, M. Serra-Prat et al., Am J Infect Control, vol. 31, no. 8, pp. 462-464, 2003.

(24) J. C. Yébenes, L. Vidaur, M. Serra-Prat, J. M. Sirvent, J. Batlle, M. Motje, A. Bonet, and M. Palomar, Am J Infect Control, vol. 32, no. 5, pp. 291-295, 2004.

* Grade of recommendation was modified from the NHMRC definitions (NHMRC, 2009) [102]. To achieve a grade of A the research is required to be a high quality randomized control trial (RCT) or a systematic review of high quality RCTs. Laboratory (in vitro) research was classified as level V evidence (DeVries and Berlet 2010 [103]; The University of Newcastle Australia, 2014 [104]).

A: body of evidence can be trusted to guide practice, systematic review or RCT

B: body of evidence can be trusted to guide practice in most situations, RCT or high quality observational study.

C: body of evidence provides some support for recommendation but care should be taken in its application, observational studies.

$\mathrm{D}$ : Level V evidence or evidence that is weak and recommendation must be applied with caution, expert opinion, animal, or laboratory studies. See Figure 1.

must be weighed with consideration for potential negative factors of design features, poor aseptic practices, and lack of disinfection that all contribute to risk of infection $[2,121,122]$.

Any puncture through the protective skin barrier creates a portal for bacteria to enter the body. Recognized routes of catheter contamination are classified as either extraluminal or intraluminal and include (a) migration of microorganisms from the skin at the insertion site (considered the source in short term infections), (b) catheter hub contamination, (c) hematogenous seeding from another infection source in the body, and (d) direct contamination from an infusate
$[8,108,123]$. After insertion of a catheter, introduction of microorganisms occurs primarily from two routes: the skin/insertion track or through the lumen of the catheter [15, 124-127]. The greatest risk for contamination of the catheter after insertion is the access hub with 33-45\% (402/900) contaminated in normal patient use $[6,15,128-132]$. In early studies by Sitges-Serra colonization of the catheter hub was considered the primary pathogenesis of catheter associated infection $[15,113]$. Linares and colleagues reported 14 episodes of sepsis (70\% of total catheter related septic events) resulted from hub-related contamination [127, 133]. 


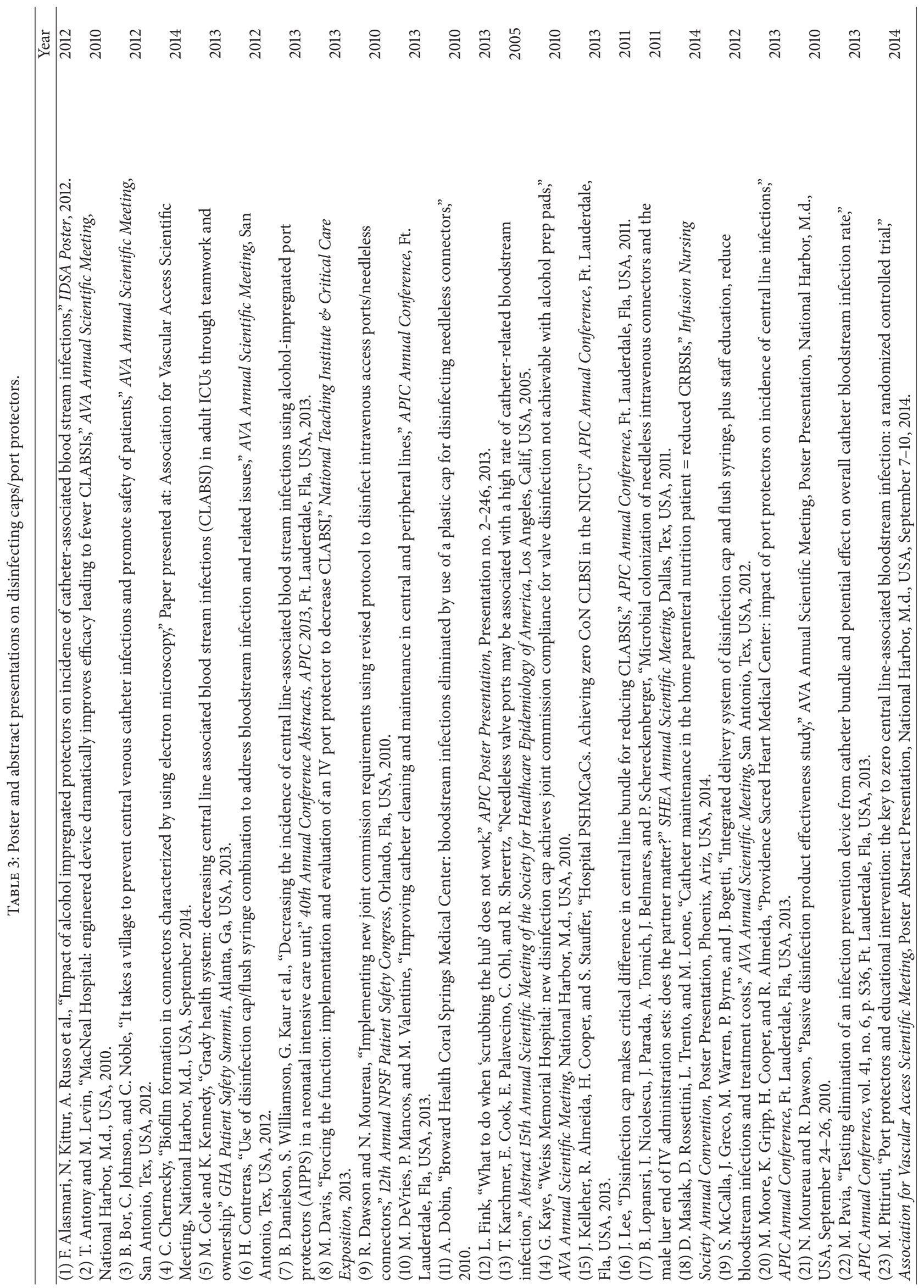




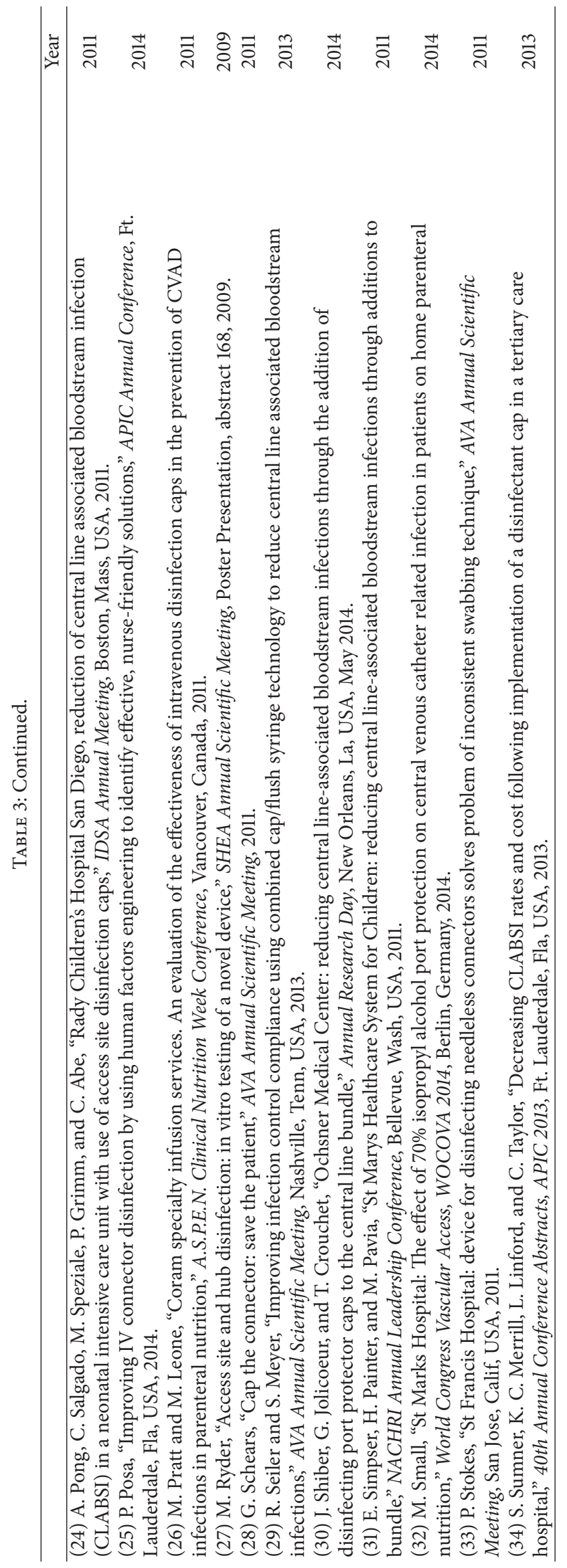


TABLE 4: Why disinfect? Sources of contamination literature.

Year

(1) B. Brismar, L. Jordahl et al., Clinical Nutrition, vol. 6, no. 1, pp. 31-33, 1984.

1984

(2) I. F. Btaiche, D. S. Kovacevich et al., Am J Infect Control, vol. 39, no. 4, pp. 277-283, 2011.

(3) A. R. Burrell, M. L. McLaws et al., Med J Aust, vol. 194, no. 11, pp. 583-587, 2011.

2011

(4) C. Chernecky, "Biofilm formation in connectors characterized by using electron microscopy," Abstract Assoc Vasc Access

Scientific Conference, National Harbor, M.d., USA, September 2014.

(5) D. Cozanitis and P. Makela, Acta anaesthesiologica Belgica, vol. 59, no. 2, pp. 59-63, 2008.

2014

(6) J. Davis, “Pennsylvania patient safety authority 2011," Patient Safety Advisory, vol. 8, no. 3, pp. 100-104, 2011.

2008

(7) R. Donlan, Curr Top Microbiol Immunol, vol. 322, pp. 133-161, 2008.

2011

(8) R. M. Donlan and J. W. Costerton, Clinical Microbiology Reviews, vol. 15, no. 2, pp. 167-193, 2002.

2008

(9) R. Donlan, Emerging Infection Diseases, vol. 7, no. 2, pp. 277-281, 2001.

2002

(10) L. Hadaway, Nursing Management, vol. 39, no. 10, p. 17, 2008.

2001

(11) L. Hadaway, J Infus Nurs, vol. 35, no. 4, pp. 230-240, 2012.

2008

(12) L. Hadaway, Journal of Infusion Nursing, vol. 26, no. 1, pp. 44-48, 2003.

2012

(13) J. Liñares, A. Sitges-Serra, J. Garau, J. Perez, and R. Martin, Journal of Clinical Microbiology, vol. 21, no. 3, pp. 357-360, 1985.

(14) B. L. Lobo, G. Vaidean et al., J Hosp Med, vol. 4, no. 7, pp. 417-422, 2009.

2003

(15) J.-C. Lucet, J. Hayon et al., Infection Control and Hospital Epidemiology, vol. 21, no. 1, pp. 40-42, 2000.

1985

(16) M. A. Luebke, M. J. Arduino, D. L. Duda et al., American Journal of Infection Control, vol. 26, no. 4, pp. 437-441, 1998.

2009

2000

(17) L. M. Mahieu, A. O. De Muynck et al., J Hosp Infect, vol. 48, pp. 108-116, 2001.

1998

(18) D. Macklin, J Assoc Vasc Access, vol. 15, no. 3, pp. 126-150, 2010.

2001

(19) D. Maki, C. E. Weise, and H. W. Sarafin, New England Journal Medicine, vol. 296, pp. 1305-1309, 1977.

2010

(20) D. Maki, Anesth Analg, vol. 56, no. 1, pp. 141-153, 1977.

1977

(21) L. A. Mermel, Clinical Infectious Diseases, vol. 52, no. 2, pp. 211-212, 2011.

1977

(22) M. L. Moro, E. F. Vigano, and A. Cozzi Lepri, Infect Control Hosp Epidemiol, vol. 15, no. 4, part 1, pp. 253-264, 1994.

2011

(23) I. Raad, W. Costerton et al., Journal of Infectious Diseases, vol. 168, no. 2, pp. 400-407, 1993.

1994

(24) I. Raad, M. Luna, S. Khalil, J. Costerton, C. Lam, and G. Bodey, JAMA, vol. 271, no. 13, pp. 1014-1016, 1994.

1993

(25) P. Ramritu, K. Halton, D. Cook, M. Whitby, and N. Graves, Journal of Advanced Nursing, vol. 62, no. 1, pp. 3-21, 2008.

1994

(26) C. M. Rickard, J. Webster, and E. G. Playford, Med J Aust, vol. 198, no. 10, pp. 519-520, 2013.

2008

(27) M. Ryder, G. Hamilton, M. Hamilton, and G. James, "Bacterial transfer through needlefree connectors: comparison of nine different devices," Society for Healthcare Epidemiology of America Annual Scientific Meeting, Baltimore, M.d., USA, 2007.

(28) M. Ryder, Topics in Advanced Practice Nursing eJournal, vol. 2005, 2005.

2007

(29) M. Ryder, Advocate, 2006.

2005

(30) M. B. Salzman, H. D. Isenberg et al., J Infect Dis, vol. 167, no. 2, pp. 487-490, 1993.

2006

(31) M. B. Salzman and L. G. Rubin, Nutrition, vol. 13, supplement 4, pp. 15s-17s, 1997.

1993

(32) N. Safdar and D. Maki, Intensive Care Med, vol. 30, no. 1, pp. 62-67, 2004.

1997

(33) A. Sitges-Serra et al., Nutrition, vol 13, supplement 4, pp. 30s-35s, 1997.

2004

(34) A. Sitges-Serra, J. Linares, and J. Garau, Surgery, vol. 97, no. 3, pp. 355-357, 1985.

1997

(35) A. Sitges-Serra, J. Linares, J. L. Perez, E. Jaurrieta, and L. Lorente, J Parenter Enteral Nutr, vol. 9, no. 3, pp. 322-325, 1985.

1985

(36) A. Sitges-Serra, P. Puig, J. Linares et al., J Parenter Enteral Nutr, vol. 8, no. 6, pp. 668-672, 1984.

1985

(37) B. W. Trautner and R. O. Darouiche, Archives of Internal Medicine, vol. 164, no. 8, pp. 842-850, 2004.

1984

(38) J. M. Walz, K. Faris, S. O. Heard, Critical Care Medicine, vol. 36, no. 9, pp. 2689-2690, 2008.

2004

2008

Moro reported hub colonization in only 3.5\% (21/607), but found that this group was responsible for severe systemic infections more frequently [128]. Studies indicate that, during periods of nonuse, colony forming units (CFU) are present on access hubs in numbers ranging from 15 to $1000 \mathrm{CFU}$, representing quantities sufficient to cause contamination, biofilm formation, and potentially bacteremia if not sufficiently disinfected prior to access $[3,5,12,99,110,111,134-$ 143]. As demonstrated by multiple studies, infections are drastically lower or eliminated by disinfecting or covering the access hub with an antimicrobial cap $[14,16-20,113$, 127, 144-146]. Hub contamination plays an increasingly 
TABLE 5: Education and compliance literature.

\begin{tabular}{|c|c|}
\hline & Year \\
\hline (1) N. Arora et al., Am J Med Qual, vol. 29, no. 4, pp. 329-334, 2013. & 2013 \\
\hline (2) K. Y. Blot et al., Crit Care Med, vol. 42, no. 5, p. e382, 2014. & 2014 \\
\hline (3) K. Blot et al., Clin Infect Dis, vol. 59, no. 1, pp. 96-105, 2014. & 2014 \\
\hline (4) C. L. Boyer, J Intraven Nurs, vol. 21, supplement 5, pp. S161-S165, 1998. & 1998 \\
\hline (5) C. Chernecky et al., Clin J Oncol Nurs, vol. 13, no. 6, pp. 630-633, 2009. & 2009 \\
\hline (6) M. G. Cherry et al., Med Teach, vol. 32, no. 3, pp. 198-218, 2010. & 2010 \\
\hline (7) M. G. Cherry et al., Med Teach, vol. 34, no. 6, pp. e406-e420, 2012. & 2012 \\
\hline (8) S. Cookson et al., Infect Control Hosp Epidemiol, vol. 19, no. 1, pp. 23-27, 1998. & 1998 \\
\hline (9) K. Cooper et al., J Hosp Infect, vol. 86, no. 1, pp. 47-52, 2014. & 2014 \\
\hline (10) C. Coopersmith, J. E. Zack, M. R. Ward et al., vol. 139, no. 2, pp. 131-136, 2004. & 2004 \\
\hline (11) M. G. Fakih et al., Infect Control Hosp Epidemiol, vol. 33, no. 5, pp. 449-455, 2012. & 2012 \\
\hline (12) B. M. Farr, Infect Control Hosp Epidemiol, vol. 21, no. 6, pp. 411-416, 2000. & 2000 \\
\hline (13) G. K. Frampton, P. Harris, K. Cooper et al., Health Technol Assess, vol. 18, no. 15, pp. 1-365, 2014. & 2014 \\
\hline (14) K. Herzer, L. Niessen et al., BMJ Open, vol. 2014, article 4, 2014. & 2014 \\
\hline (15) Y. J. Hsu, K. Weeks et al., Am J Infect Control, vol. 42, supplement 10, pp. S191-196, 2014. & 2014 \\
\hline (16) J. M. Jardim, R. A. Lacerda et al., Revista da Escola de Enfermagem da USP, vol. 47, no. 1, pp. 38-45, 2013. & 2013 \\
\hline (17) I. S. Jeong, S. M. Park, J. M. Lee, J. Y. Song, and S. J. Lee, Am J Infect Control, vol. 41, no. 8, pp. 710-716, 2013. & 2013 \\
\hline (18) R. D. Lobo, A. S. Levin, L. M. Gomes et al., Am J Infect Control, vol. 33, no. 2, pp. 83-87, 2005. & 2005 \\
\hline (19) D. Macklin, C. Chernecky, K. Nugent, J. Waller, Journal of Vascular Access Devices, vol. 8, no. 2, pp. 8-13, 2003. & 2003 \\
\hline (20) A. S. McAlearney, J. L. Hefner, Am J Infect Control, vol. 42, supplement 10, pp. S216-222, 2014. & 2014 \\
\hline (21) M. McGuckin, R. Waterman, L. Porten et al., Am J Infect Control, vol. 27, no. 4, pp. 309-314, 1999. & 1999 \\
\hline (22) A. Mian, C. Russell, M. Honeycutt, and C. Oldridge, J Ark Med Soc, vol. 109, no. 7, pp. 128-131, 2012. & 2012 \\
\hline (23) N. Moureau, "Winning the war on CLABSIs: the role of education and new technology" ICT, 2009. & 2009 \\
\hline (24) D. Platace, I. Klava, L. Antonevica et al., Acta Chirurgica Latviensis, vol. 9, no. 1, pp. 50-55, 2010. & 2010 \\
\hline $\begin{array}{l}\text { (25) P. Pronovost, D. Needham, S. Berenholtz et al., The New England Journal of Medicine, vol. 355, no. 26, pp. 2725-2732, } \\
\text { 2006. }\end{array}$ & 2006 \\
\hline (26) P. Rangachari, Qual Manag Health Care, vol. 22, no. 1, pp. 16-24, 2013. & 2013 \\
\hline (27) G. D. Sacks, B. S. Diggs et al., Am J Surg, vol. 207, no. 6, pp. 817-823, 2014. & 2014 \\
\hline (28) J. Segreti, S. Garcia-Houchins, L. Gorski et al., JIN, vol. 34, no. 2, pp. 126-133, 2011. & 2011 \\
\hline (29) J. S. Smith, K. M. Kirksey, H. Becker, A. Brown, J Infus Nurs, vol. 34, no. 3, pp. 193-200, 2011. & 2011 \\
\hline (30) D. Warren, J. Zack, and J. Mayfield, CHEST, vol. 126, no. 5, pp. 1612-1618, 2004. & 2004 \\
\hline (31) D. K. Warren et al., Infect Control Hosp Epidemiol, vol. 27, no. 7, pp. 662-669, 2006. & 2006 \\
\hline (32) D. K. Warren, D. S. Yokoe, M. W. Climo et al., Infect Control Hosp Epidemiol, vol. 27, no. 1, pp. 8-13, 2006. & 2006 \\
\hline $\begin{array}{l}\text { (33) D. K. Warren, J. E. Zack, M. J. Cox, M. M. Cohen, and V. J. Fraser, Critical Care Medicine, vol. 31, no. 7, pp. 1959-1963, } \\
2003 .\end{array}$ & 2003 \\
\hline (34) E. Young, M. Commiskey, S. Wilson, Am J Infect Control, vol. 34, no. 8, pp. 503-506, 2006. & 2006 \\
\hline (35) W. Zingg, A. Imhof, M. Maggiorini et al., Critical Care Medicine, vol. 37, no. 7, pp. 2167-2173, 2009. & 2009 \\
\hline
\end{tabular}

important role with infection risk the longer the catheter is in place [15]. Intraluminal contamination and subsequent colonization become more prominent with longer dwell times [110,147]. Perez and associates found 59\% (42/75) of one group of NC colonized with biofilm and Salzman found that $71 \%(20 / 28)$ of catheter related infections originated in the catheter hub presumably from contamination $[15,21,22,148]$. Clearly hub contamination is a causative element in catheter related infections and one that demonstrates the necessity for effective hub disinfection prior to access $[110,113,127,133,144$, 149].
3.2. What to Disinfect? Disinfection points to gain access to intravenous or intravascular devices may include tubing side ports, direct catheter connections, stopcocks with needle free caps, NC of various types (split septum, mechanical valves, positive pressure valves, zero, or neutral connectors), traditional silicone septum, or other forms of access integrated with the catheter or tubing. Any intravascular access point with a surface open to the environment requires disinfection prior to use, as it acts as the immediate portal of entry for intraluminal contaminants $[23,99,113,127,133,144,150-$ 152]. Needle free devices constitute more than $80 \%$ of access 
TABLE 6

\begin{tabular}{|c|c|c|}
\hline & Recommendations for disinfecting practices & $\begin{array}{l}\text { Levels of } \\
\text { evidence* }^{*}\end{array}$ \\
\hline 1 & $\begin{array}{l}\text { Use disinfection on surfaces of needleless connectors, stopcocks and other intravascular } \\
\text { access ports immediately prior to any connection, infusion or aspiration with appropriate } \\
\text { antiseptic agent (e.g., alcoholic chlorhexidine, povidone iodine, an iodophor, or } 70 \% \\
\text { alcohol). Access catheter connections with sterile devices only [8-11]. }\end{array}$ & B \\
\hline 2 & $\begin{array}{l}\text { Antimicrobial caps/port protectors may be effectively used for passive continuous hub } \\
\text { disinfection on needleless connections in accordance with manufacturer instructions, in } \\
\text { conjunction with frictional antiseptic wiping between applications and access } \\
{[2,6,10,12-51] \text {. }}\end{array}$ & B-C \\
\hline 3 & $\begin{array}{l}\text { Ensure compliance with hand hygiene, gloving and aseptic practices prior to any contact } \\
\text { with intravenous devices and add-on equipment }[6,8,10,30,52-59] \text {. }\end{array}$ & B \\
\hline 4 & $\begin{array}{l}\text { Establish and educate all clinical staff on a standard protocol to disinfect catheter hubs, } \\
\text { needleless connectors and ports prior to and after each access }[11,20,60-63] .\end{array}$ & B-C \\
\hline 5 & $\begin{array}{l}\text { Provide consistent and varied staff education on consequences of poor technique along with } \\
\text { clinical reminders of best practice }[10,13,51,54,60,64-87] \text {. }\end{array}$ & $\mathrm{C}$ \\
\hline 6 & $\begin{array}{l}\text { Establish regular surveillance of compliance for disinfection of intravascular devices prior to } \\
\text { access with reporting of results to each care unit }[1,67,72,78,88-96] \text {. }\end{array}$ & $\mathrm{C}$ \\
\hline 7 & $\begin{array}{l}\text { Establish a formal process to evaluate new technology and needleless connector designs } \\
{[7,71,97,98] \text {. }}\end{array}$ & A \\
\hline 8 & $\begin{array}{l}\text { Implement a multimodal quality improvement infection prevention program that applies } \\
\text { guidelines and recommendations to all intravascular practices }[68,78,85,99-101] \text {. }\end{array}$ & B \\
\hline \multicolumn{3}{|c|}{$\begin{array}{l}\text { * Grade of recommendation was modified from the NHMRC definitions (NHMRC, 2009) [102]. To achieve a grade of A the re } \\
\text { high quality randomized control trial (RCT) or a systematic review of high quality RCTs. Laboratory (in vitro) research was cla } \\
\text { (DeVries and Berlet, } 2010 \text { [103]; The University of Newcastle Australia, } 2014 \text { [104]). } \\
\text { A: body of evidence can be trusted to guide practice, systematic review or RCT. } \\
\text { B: body of evidence can be trusted to guide practice in most situations, RCT or high quality observational study. } \\
\text { C: body of evidence provides some support for recommendation but care should be taken in its application, observational studies. } \\
\text { D: Level V evidence or evidence that is weak and recommendation must be applied with caution, expert opinion, animal, or labora }\end{array}$} \\
\hline
\end{tabular}

devices, are recommended by Centers for Disease Control for all tubing/catheter access, and are now more common than traditional covered septal access ports which allowed needles to pass easily through the silicone or rubber covered access $[8,153]$. Primary areas of focus for disinfection of access sites are the point where the sterile syringe or tubing contacts the site, as in the top septum surface, and the threads or side surfaces $[7,143,154]$. Manufacturers are required to include instructions for device use and disinfection recommendations with each product to guide in the correct and safe usage of the NC.

Effective disinfection of a NC is influenced by several factors including: ability to clean the NC surface, the amount and position of grooves or gaps present, and the roughness or smoothness of the septum $[1,3,7,69,150,154-156]$. All NC consist of a septum, a fluid pathway and a mechanism for activation; the design, space, volume, and human factors all affect how easy a product is to use and disinfect, and may also act as contributors to the potential risk of catheter associated bloodstream infection $[3,69,150,155,157,158]$. NC have gaps of differing widths between the septal seal and the housing which may allow ingress of microorganisms $[7,23$, 99, 143]. Adequate cleaning or need for additional cleaning of the septal access site may be based on the specific design features of the individual NC $[2,4,5,7,70,111,129,153,159$ 161]. New products or technology should be transitioned into a healthcare facility only after a complete evaluation of both the research and the performance of the product to determine the impact of the change on patient outcomes [71, 97, 98, 149, $160,162-166]$.

3.3. Disinfection Practices. Recommendations from both the Centers for Disease Control and the Infusion Nurses Society state clinician should minimize contamination risk by disinfection the access ports of the add-on device using friction with an appropriate disinfectant (70\% alcohol, chlorhexidine, povidone iodine, and iodophors) prior to any access [8, $11,24,167,168]$. The $70 \%$ isopropyl alcohol wipe is most commonly used to disinfect the access surface of NC and has been proven effective or ineffective at disinfection times from 5 seconds to 60 seconds [14, 19, 24-27, 131, 151, 169177]. The major biocide effect of alcohol occurs while wet and immediately after drying, allowing for dehydration of bacterial cells, whereas alcoholic chlorhexidine is most effective during the drying process, where it enters the cell to cause destruction providing ongoing antimicrobial effect $[150,172]$. The disinfecting action of chlorhexidine in combination with alcohol, allowing for both immediate and sustained action; has proven to be more effective than either agent alone $[21,131,168,172,176,178-180]$. Faster drying time with alcohol makes it superior to other disinfection agents and provides an advantage to chlorhexidine when used 
in combination. Effectiveness of $70 \%$ alcohol disinfection is variable based on application techniques and characteristics of NC surface and design, leading some researchers to conclude that complete disinfection of microorganisms on some NC surfaces may not be achievable [12]. In the Menyhay prospective in vitro study, 20 (67\%) of $30 \mathrm{NC}$ disinfected with $70 \%$ alcohol resulted in transmission of contaminants (442-25,000 CFU) yet 60 tested with barrier caps (containing $2 \%$ chlorhexidine and $70 \%$ alcohol) showed only one (1.6\%) with transmission of contaminants [19]. In both the Kaler laboratory and the Ruschman randomized experimental design studies, using a 15 second and 60 second scrub respectively, disinfection with $70 \%$ alcohol eliminated all microorganisms [173, 181]. Kaler performed laboratory testing on contaminated NC with a small sample using $70 \%$ alcohol and alcoholic chlorhexidine and found both to be effective for hub disinfection [181]. Two additional studies gave conflicting results. Rupp demonstrated 5 second alcohol disinfection was effective; this was in direct contrast with the Smith study where contact time of 10/12/15 seconds was deemed adequate, but 5 and 8 seconds were not as effective to prevent bacterial transfer $[170,171]$. Simmons and colleagues found 3/10/15 seconds significantly decreased the bacterial load in an in vitro laboratory study, with some level of bacteria remaining during all duration levels tested; disinfection failed to completely eliminate contaminants [13]. More studies are needed to provide efficacy for optimal time necessary to eliminate surface contaminants.

Research of Macias and associates with 2\% chlorhexidine in $70 \%$ isopropyl alcohol on skin proved an added substantive effect, even against freshly introduced organisms, for up to 24 hours, establishing this agent as a superior disinfecting agent when longer action is needed, in comparison with single agents of $70 \%$ isopropyl alcohol, $10 \%$ povidone iodine and $10 \%$ sodium hypochlorite [172]. Alcoholic chlorhexidine performed consistently well or better than other disinfection agents in multiple studies [21, 24, 131, 168, 172, 179, 182]. In the research by Hong et al., a 5 second scrub with alcoholic chlorhexidine fully disinfected NC surfaces treated with Pseudomonas Aeruginosa [179]. In the most recent Epic3 United Kingdom report of evidence-based guidelines, recommendations by expert consensus include a 15 second cleansing with alcoholic chlorhexidine prior to and after each access [53]. In actual practice disinfection prior to access is expected, while cleansing after each access is rarely done.

3.4. Passive Disinfection. Disinfection research includes various forms of passive antimicrobial hub protection with 70\% alcohol caps (SwabCap, Excelsior Medical, Neptune, NJ; Curos Port Protector, Ivera Medical, San Diego, CA; EffectIV-Cap, Hospira, Lake Forest, IL; DualCap, Catheter Connections, Salt Lake City, UT), iodinated alcohol hub, povidone iodine gauze and specialty covers, and combination chlorhexidine/alcohol caps $[12,14,18,19,23,25-43,146$, 178, 183-192]. In a randomized prospective trial by Pittiruti, 46 catheters received a $70 \%$ alcohol port protector with no detected CLABSIs over 707 catheter days, colonization in two catheters and no contaminated blood cultures [18]. Of note the Pittiruti study resulted in reductions of CLABSIs in the port protector/disinfection cap group and the control group, with improvements attributed to both the disinfection caps and educational efforts. These disinfection caps applied and left in place provide active mechanical friction along with longer contact time creating a physical and chemical barrier between the lumen and the environment [26]. As a progressive CLABSI intervention Posa at St. Joseph Mercy Health System implemented an insertion bundle, chlorhexidine bathing, a maintenance bundle, chlorhexidine dressing for central catheters, and educational programs, however it was not until implementing the $70 \%$ alcohol disinfection cap that their rates of CLABSI fell to zero and remained from 2011 to the end of 2012 The disinfection cap placed on all access ports eliminates human factor issues requiring clinicians to remember to carry the necessary disinfection supplies to the bedside or even to remember to perform the act of disinfection before each access [187]. An in vivo hospital study by DeVries gave nurses a choice to use either this single use cleansing cap or a disinfection cap to leave on the NC access site, clinicians preferred the longer lasting disinfection cap [14]. In another retrospective study, Schears noted a predisinfection cap CLABSI rate of 1.682/1000 catheter days and a CLABSI rate of 0.6461/1000 catheter days after implementing disinfection caps, representing a statistically significant $61 \%$ reduction in CLABSI [32]. In Wright et al's study at NorthShore University HealthSystem, a four University Hospital system, the intervention with $70 \%$ alcohol disinfection caps reported CLABSI rates declining from 1.42/1000 catheter days $(16 / 11,540)$ to $0.69(13 / 18,972)$ with a $95 \%$ confidence interval, based on 799 enrolled patients, representing a statistically significant decrease [26]. Another alcoholic hub protector study by Sweet et al. included 472 patients and 3005 catheter days and showed a decrease in overall CLABSIs from 2.3 to $0.3 / 1000$ catheter days and a PICC CLABSI reduction from 2.3 to 0 , a statistically significant change, with an $85.2 \%$ compliance rate [31]. Stango and associates reported a $50 \%$ reduction in CLABSIs and a savings of $\$ 464,440$ per year after alcoholic cap implementation [184]. Numerous studies have demonstrated consistent clinical effectiveness of $70 \%$ alcohol caps alone in studies and abstracts graded C or D [18, 26, 27, 31, 33, 41, 43, 178, 189, 191-194]. Alcoholic chlorhexidine caps are also effective in preventing contamination and completely disinfecting $\mathrm{NC}$ access surfaces (combination of alcoholic chlorhexidine in cap form is not commercially available in the USA) $[2,12,19,178,179]$.

Another engineered solution for hub cleaning involves a 70\% alcohol foam cap (Site Scrub, Bard Access, Salt Lake City, UT) designed for use as an access site cleansing cap for single use, then discarded. The Holroyd in vitro study at University of Florida compared the single use of this cleansing cap with 70\% alcohol to traditional 70\% alcohol wipes [151]. When the cleansing cap was used on stopcocks Holroyd found contamination and increased CFU. This study found $70 \%$ alcohol wipes and this alcohol cleansing cap were both effective on the surface of NC and catheter hubs [151]. Other groups also used this single use cleansing cap in combination with other $70 \%$ alcohol disinfecting caps designed to be left in place until the next access $[14,177]$. 
3.5. Clinical Implications. Since the advent of NC as access hubs for the administration of medications or fluids, there has been a need to verify compliance with disinfection practices prior to access. During the period of needle usage for catheter access, nurses and doctors intuitively knew the necessity of disinfecting the access septum prior to inserting a needle. With NC, these questions arise: is disinfection always performed prior to access? Is disinfection performed in an effective manner? Do clinicians fully understand the consequences of not performing disinfection? Disinfection practices with alcohol or alcoholic chlorhexidine that include adequate contact disinfection time are effective if performed at all. According to a recent publication by Ryder, an issue was raised regarding whether failure to disinfect is considered a medical error and if so, is this omission considered negligence? [100] Catheter associated infections are a significant safety issue, and contamination caused by lack of aseptic technique is preventable. Once contamination occurs, bacteria attach to the inner lumen of the catheter, begin to grow and form biofilm, making successful eradication extremely difficult [6, 28-30, 113, 127, 133, 140-142, 144, 195]. Joint Commission now requires hospitals in the USA to protect patients by having a standard and measurable protocol for hub/access site disinfection [61, 62, 196]. Measurement of compliance with hub disinfection is challenging, requiring direct observation of the action unless disinfection caps/ports are used on all NC hubs as a form of verification. Passive disinfection through hub protectors/disinfection caps have differing designs and colors, leading to easy recognition and validation of compliance with usage. Reimbursement structures in the USA that now promote pay for performance and penalize poor outcomes will assist in driving these passive safety strategies that aid in monitoring and improving compliance with disinfection.

3.6. Issues of Compliance and Monitoring. While policies for disinfection of access devices are a first step, methods to validate actual practice and patient safety must be integrated into hospital culture. The central line bundle checklist is used as evidence to demonstrate compliance with safety practices during insertion, but the aspect of day to day management is not addressed in the bundle. Care and management of catheters takes up more than $99 \%$ of the dwell time of a catheter compared to the one hour or less for catheter insertion. Compliance with aseptic practice is important for both insertion and daily usage. Consistent hand hygiene and gloving performed prior to any procedure or even touching of a catheter helps reduce bacterial transfer. Application of alcoholic chlorhexidine to disinfect skin for central line insertions and now, more and more with peripheral catheter insertions, is helping to reduce bacterial ingress to the bloodstream. Maximum sterile barriers also reduce contamination during the insertion process so that overall, CLABSI rates occurring in the first few days of insertion continue to fall.

Even with the success of the Central Line Bundle on CLABSI reductions, a majority of hospitals remain well above zero for infections. Access and maintenance activities with the catheters may be to blame. When CLABSIs occur well after the 96 hour mark, contamination of the catheter through the NC is likely the culprit. From the evidence presented, $\mathrm{NC}$ and catheter hubs are a primary source of bacterial contamination, and subsequent transmission of contamination into the catheter lumen $[6,30,113,127,133,142$, 144]. Just one omission of scrubbing the hub prior to access permits bacterial entry, attachment and biofilm formation that allow the bacteria to strengthen prior to release into the bloodstream. Preventing this form of contamination requires teaching and constant reinforcement of the required practice of regular and consistent disinfection prior to every access. Verification of compliance with hub disinfection by clinicians requires direct observation of the action unless disinfection hub protectors are used, providing a form of passive immediate visual verification. More and more studies are demonstrating lack of compliance with hub disinfection despite educational initiatives and better disinfection agents. Disinfection methods that incorporate prolonged duration of contact with an antiseptic agent to significantly decrease the level of surface bacteria present may provide a solution to the problem of hub contamination and variation in $\mathrm{NC}$ designs.

Various studies provide statements regarding conformity or lack of conformity concerning disinfection practices, attributing noncompliance to a lack of universal protocols, excessive workloads (e.g., when clinicians become busy, they are less likely to comply), or just forgetting to bring alcohol wipes to the bedside $[54,64,72,89-93,188]$. The Smith study on behavioral intention indicated a negative correlation between performing optimal disinfection with increasing age of clinicians and more years of experience [91]. Clearly there are human factors working against disinfection of hubs prior to access requiring engineered solutions such as passive disinfecting cap strips hanging on intravenous pump poles, supply dispensers of alcohol wipes at the bedside, or on the intravenous pump to ensure greater, even 100\% compliance with disinfection each and every time [91, 170]. Monitoring and validation of hub disinfection compliance is necessary to determine if other measures are needed such as disinfection caps/port protectors. In an evaluation of 5877 physicians, nurses and technicians, Jardim et al. documented compliance with hub disinfection $38.7 \%$ of the time, leaving more than $61 \%$ of accesses without disinfection, leading to possible contamination and biofilm growth [92]. Platace et al. evaluated clinician hands during invasive procedures demonstrating $100 \%$ of the 48 nurses sampled exceeded acceptable levels of microorganisms, with the potential to contaminate and cause bloodstream infection [90]. Studies show there is a need for clear recommendations and practices that prevent transmission of contaminants through NC $[68,90]$. Targeting of education for providers responsible for CVAD insertion and care for identifying appropriate indications, performing insertion with the central line bundle, performing surveillance of CLABSI and scrubbing the hub with an appropriate antiseptic are Category IA recommendations by AHRQ as critical components of a comprehensive CLABSI prevention program [9]. 
3.7. Risk of Bias and Limitations. This systematic review highlights the lack of available high quality research in this area that tests the cause and effect relationship between NC disinfection practices and patient infection outcomes. It also asks the question "What are we basing our clinical practice guidelines on for disinfection of NC?" Absence of high quality RCT evidence required authors to include any clinical observational and cohort studies and laboratory studies. Overall, the evidence base for the effectiveness of various disinfection strategies is low level, resulting in recommendations compiled from the available publications. The strength of this review is that it includes all relevant, currently available pieces of evidence; however there remains a high level of uncertainty in the estimates of effectiveness of various decontamination techniques, and these are highly likely to change with the publication of new studies in the literature. Studies to date have a risk of unintentional bias due to the lack of randomization and control groups/strategies, in addition to small sample sizes and retrospective study designs. Randomized controlled studies are needed to rigorously evaluate the efficacy of disinfection practices and antiseptic hub protectors in preventing patient infection.

3.8. Research Priorities. Adequately large randomized controlled trials are urgently needed to establish high quality evidence of the efficacy of various disinfection practices to prevent infection. Randomized controlled trials are needed to identify if risk reduction differs with the type of antiseptic, for example, 70\% alcohol versus 70\% alcohol and chlorhexidine, or with differing concentrations of chlorhexidine in their efficacy for disinfection NC. Research may also validate the substantive effect of alcoholic chlorhexidine on NC and its continued antimicrobial activity on these surfaces, potentially establishing a reduced cleaning frequency or duration for NC. Study considerations for passive disinfection coupled with prefilled flush syringes could demonstrate drastic reduction of hub contamination and intraluminal biofilm colonization, but ultimately patient infection outcomes are needed. Research that replicates solid studies provides a stronger foundation for evidence-based practice and should be encouraged. Translational research is growing, providing clinical implications that directly apply to bedside practices $[14,57-59,67,70,73-75]$. NC disinfection is an excellent subject for efficacy studies utilizing comparative research for various disinfection approaches identifying relative reductions in patient infection risk. Claire Rickard, Ph.D., Professor of Nursing with Griffith University, states it well "We are belatedly realising that to eliminate these complications (infections) we must conduct research, implement evidencebased interventions and reduce the clinical practice variations that lead to their occurrence" [197]. Research and study are necessary as an integral part of professional practice, providing a means to direct clinical activity and to share with rising young clinicians long after we are gone.

\section{Conclusion}

Aseptic technique is the foundation for safe delivery of intravenous medications and solutions. More and more studies reveal lack of compliance with disinfection of access ports prior to and after access, despite educational initiatives, and better disinfection agents $[1,26,27,38,54,57,64$, $67,69,72,74,78,83,88-93,188,198-205]$. Rather than creating devices such as the ultraviolet $\mathrm{C}$ port to eradicate contamination within the hub, the goal should be to eliminate surface pathogens before entering the NC or catheter. Passive disinfection caps reduce guess work, provide clinicians with a point of use solution, and reduce contamination. It is critical for healthcare facilities and clinicians to take responsibility for compliance with aseptic technique for NC disinfection, to monitor compliance regularly, to involve frontline staff in solutions, and to facilitate education that promotes understanding of the consequences of failure to comply with the standard of care for access site disinfection.

\section{Conflict of Interests}

Open access fees were paid by first author. Nancy L. Moureau is a speaker and educational consultant with $3 \mathrm{M}$, Access Scientific, Analogic, Angiodynamics, Arrow/Teleflex, Baxter, Carefusion, Cook, Excelsior, Genentech, Hospira, Nexus, Vascular Pathways, and Vygon; chief executive officer of PICC Excellence, Inc., and clinician at Greenville Memorial Hospital. Julie Flynn is a research doctorate candidate (April, 2015) with the Alliance for Vascular Access Teaching and Research, Griffith University, and active clinician at Royal Brisbane and Women's Hospital.

\section{Authors' Contribution}

Nancy L. Moureau was responsible for the study design, searches and selection of publications, analysis of selected studies, and drafting of the paper. Julie Flynn performed grading of selected publications and contributed to second paper revision.

\section{Acknowledgments}

The author wishes to thank Gigi Macher, Nancy League, and Charles Rushing, M.D., for their assistance in organizing, reviewing materials, and editing the paper and Griffith University, Samantha Keogh, and Claire Rickard for facilitating access to literature review and allocation of resources for grading of the studies.

\section{References}

[1] L. Hadaway, "Needleless connectors: Improving practice, reducing risks," Journal of the Association for Vascular Access, vol. 16, no. 1, pp. 20-30, 2011.

[2] I. F. Btaiche, D. S. Kovacevich, N. Khalidi, and L. F. Papke, “The effects of needleless connectors on catheter-related bloodstream infections," American Journal of Infection Control, vol. 39, no. 4, pp. 277-283, 2011.

[3] W. R. Jarvis, C. Murphy, K. K. Hall et al., "Health careassociated bloodstream infections associated with negative- or positive-pressure or displacement mechanical valve needleless 
connectors," Clinical Infectious Diseases, vol. 49, no. 12, pp. 18211827, 2009.

[4] E. Bouza, P. Muñoz, J. López-Rodríguez et al., "A needleless closed system device (CLAVE) protects from intravascular catheter tip and hub colonization: a prospective randomized study," Journal of Hospital Infection, vol. 54, no. 4, pp. 279-287, 2003.

[5] C. Chernecky and J. Waller, "Comparative evaluation of five needleless intravenous connectors," Journal of Advanced Nursing, vol. 67, no. 7, pp. 1601-1613, 2011.

[6] A. Sitges-Serra, "Strategies for prevention of catheter-related bloodstream infections," Supportive Care in Cancer, vol. 7, no. 6, pp. 391-395, 1999.

[7] W. Jarvis, "Choosing the best design for intravenous needleless connectors to prevent healthcare-associated bloodstream infections," Infection Control Today, vol. 14, no. 8, pp. 1-3, 2010.

[8] N. P. O’Grady, M. Alexander, L. A. Burns et al., "Guidelines for the prevention of intravascular catheter-related infections," Clinical Infectious Diseases, vol. 52, no. 9, pp. e162-e193, 2011.

[9] V. Chopra, S. Krein, R. Olmstead, N. Safdar, and S. Saint, "Prevention of central line-associated bloodstream infections: brief update review," in Making Health Care Safer II: An Updated Critical Analysis of the Evidence for Patient Safety Practices. Comparative Effectiveness Review No. 211, chapter 10, pp. 88109, RAND Corporation, US Department of Health and Human Services, Agency for Healthcare Research and Quality, Santa Monica, Calif, USA, 2013.

[10] J. M. D. Marschall, L. A. D. O. S. Mermel, M. M. D. M. P. H. Fakih et al., "Strategies to prevent central line-associated bloodstream infections in acute care hospitals: 2014 update," Infection Control and Hospital Epidemiology, vol. 35, no. 7, pp. 753-771, 2014.

[11] INS, "Infusion nursing standards of practice," Journal of Infusion Nursing Supplement, vol. 34, supplement 1, pp. S1-S110, 2011.

[12] S. Z. Menyhay and D. G. Maki, "Disinfection of needleless catheter connectors and access ports with alcohol may not prevent microbial entry: the promise of a novel antisepticbarrier cap," Infection Control and Hospital Epidemiology, vol. 27, no. 1, pp. 23-27, 2006.

[13] S. Simmons, C. Bryson, and S. Porter, “'Scrub the hub': cleaning duration and reduction in bacterial load on central venous catheters," Critical Care Nursing Quarterly, vol. 34, no. 1, pp. 3135, 2011.

[14] M. DeVries, P. S. Mancos, and M. J. Valentine, "Reducing bloodstream infection risk in central and peripheral intravenous lines: Initial data on passive intravenous connector disinfection," The Journal of the Association for Vascular Access, vol. 19, no. 2, pp. 87-93, 2014.

[15] M. B. Salzman and L. G. Rubin, "Relevance of the catheter hub as a portal for microorganisms causing catheter-related bloodstream infections," Nutrition, vol. 13, no. 4, supplement, pp. 15s-17s, 1997.

[16] D. P. Halpin, P. O’Byrne, G. McEntee, T. P. J. Hennessy, and R. B. Stephens, "Effect of a Betadine connection shield on central venous catheter sepsis," Nutrition, vol. 7, no. 1, pp. 33-34, 1991.

[17] A. T. Stotter, H. Ward, A. H. Waterfield, J. Hilton, and A. J. Sim, "Junctional care: the key to prevention of catheter sepsis in intravenous feeding," Journal of Parenteral and Enteral Nutrition, vol. 11, no. 2, pp. 159-162, 1987.

[18] M. Pittiruti, "Port protectors and educational intervention: the key to zero central line-associated bloodstream infection-a randomized controlled trial," in Proceedings of the Association for Vascular Access Scientific Meeting, National Harbor, Md, USA, September 2014.

[19] S. Z. Menyhay and D. G. Maki, "Preventing central venous catheter-associated bloodstream infections: development of an antiseptic barrier cap for needleless connectors," The American Journal of Infection Control, vol. 36, no. 10, pp. S174-e1, 2008.

[20] N. Moureau and R. Dawson, "Passive disinfection product effectiveness study," in Proceedings of the AVA Annual Scientific Meeting, National Harbor, Md, USA, September 2010.

[21] M. B. Salzman, H. D. Isenberg, and L. G. Rubin, "Use of disinfectants to reduce microbial contamination of hubs of vascular catheters," Journal of Clinical Microbiology, vol. 31, no. 3, pp. 475-479, 1993.

[22] M. B. Salzman, H. D. Isenberg, J. F. Shapiro, P. J. Lipsitz, and L. G. Rubin, "A prospective study of the catheter hub as the portal of entry for microorganisms causing catheter-related sepsis in neonates," Journal of Infectious Diseases, vol. 167, no. 2, pp. 487490, 1993.

[23] M. Ryder, "Access site and hub disinfection: in vitro testing of a novel device," in Proceedings of the SHEA Annual Scientific Meeting, Abs \#168, 2009.

[24] A. L. Casey, S. Burnell, H. Whinn, T. Worthington, M. H. Faroqui, and T. S. J. Elliott, "A prospective clinical trial to evaluate the microbial barrier of a needleless connector," Journal of Hospital Infection, vol. 65, no. 3, pp. 212-218, 2007.

[25] J. P. Kennedy, R. A. Lasher, D. Solomon, and R. W. Hitchcock, "Disinfection of male luer style connectors for prevention of catheter related bloodstream infections using an isopropyl alcohol dispensing cap," Journal of Medical Devices, vol. 4, no. 2, Article ID 027509, 2010.

[26] M.-O. Wright, J. Tropp, D. M. Schora et al., "Continuous passive disinfection of catheter hubs prevents contamination and bloodstream infection," The American Journal of Infection Control, vol. 41, no. 1, pp. 33-38, 2013.

[27] C. Ramirez, A. M. Lee, and K. Welch, "Central venous catheter protective connector caps reduce intraluminal catheter-related infection," Journal of the Association for Vascular Access, vol. 17, no. 4, pp. 210-213, 2012.

[28] M. Segura, C. Alia, J. Valverde, G. Franch, J. M. T. Rodriguez, and A. Sitges-Serra, "Assessment of a new hub design and the semiquantitative catheter culture method using an in vivo experimental model of catheter sepsis," Journal of Clinical Microbiology, vol. 28, no. 11, pp. 2551-2554, 1990.

[29] M. Segura, F. Alvarez-Lerma, J. M. Tellado et al., "A clinical trial on the prevention of catheter-related sepsis using a new hub model," Annals of Surgery, vol. 223, no. 4, pp. 363-369, 1996.

[30] A. Sitges-Serra, R. Hernandez, S. Maestro, T. Pi-Suner, J. M. Garces, and M. Segura, "Prevention of catheter sepsis: the hub," Nutrition, vol. 13, no. 4, pp. 30s-35s, 1997.

[31] M. A. Sweet, A. Cumpston, F. Briggs, M. Craig, and M. Hamadani, "Impact of alcohol-impregnated port protectors and needleless neutral pressure connectors on central lineassociated bloodstream infections and contamination of blood cultures in an inpatient oncology unit," The American Journal of Infection Control, vol. 40, no. 10, pp. 931-934, 2012.

[32] G. Schears, "Cap the connector: save the patient," in Proceedings of the AVA Annual Scientific Meeting, 2011.

[33] M. Pratt and M. Leone, "Coram spcialty infusion services: an evaluation of the effectiveness of intravenous disinfection caps in the prevention of CVAD infections in parenteral nutrition," in Proceedings of the A.S.P.E.N. Clinical Nutrition Week Conference, Vancouver, Canada, 2011. 
[34] D. Maslak, D. Rossettini, L. Trento, and M. Leone, "Maintenance in the home parenteral nutrition patient = reduced CRBSIs," in Proceedings of the Infusion Nursing Society Annual Convention, Phoenix, Ariz, USA, 2014.

[35] H. Contreras, "Use of disinfection cap/flush syringe combination to address bloodstream infection and related issues," in Proceedings of the Annual Scientific Meeting of the Association for Vascular Access (AVA '12), San Antonio, Tex, USA, 2012.

[36] S. McCalla, J. Greco, M. Warren, P. Byrne, and J. Bogetti, "Integrated delivery system of disinfection cap and flush syringe, plus staff education, reduce bloodstream infections and treatment costs," in Proceedings of the AVA Annual Scientific Meeting, San Antonio, Tex, USA, 2012.

[37] B. Bor, C. Johnson, and C. Noble, "It takes a village to prevent central venous catheter infections and promote safety of patients," in Proceedings of the AVA Annual Scientific Meeting, San Antonio, Tex, USA, 2012.

[38] G. Kaye and T. Anthony, "Weiss memorial hospital: new disinfection cap achieves joint commission compliance for valve disinfection not achievable with alcohol prep pads," in Proceedings of the AVA Annual Scientific Meeting, National Harbor, Md, USA, 2010.

[39] M. Pavia, “Testing elimination of an infection prevention device from catheter bundle and potential effect on overall catheter bloodstream infection rate," in Proceedings of the APIC Annual Conference, vol. 41, p. S36, Fort Lauderdale, Fla, USA, 2013.

[40] S. Sumner, K. C. Merrill, L. Linford, and C. Taylor, "Decreasing CLABSI rates and cost following implementation of a disinfectant cap in a tertiary care hospital," American Journal of Infection Control, vol. 41, no. 6, p. S37, 2013, 40th Annual Conference Abstracts, Ft. Lauderdale, Fla, USA, APIC 2013.

[41] B. Danielson, S. Williamson, G. Kaur et al., "Decreasing the incidence of central line-associated blood stream infections using alcohol-impregnated port protectors (AIPPS) in a neonatal intensive care unit," in Proceedings of the 40th Annual Conference Abstracts (APIC '13), Fort Lauderdale, Fla, USA, 2013.

[42] J. Kelleher, R. Almeida, H. Cooper, and S. Stauffer, "Providence sacred heart medical center and children's hospital: achieving zero CoN CLBSI in the NICU," in Proceedings of the APIC Annual Conference, Fort Lauderdale, Fla, USA, 2013.

[43] M. Moore, K. Gripp, H. Cooper, and R. Almeida, "Providence sacred heart medical center: impact of port protectors on incidence of central line infections," in Proceedings of the 40th Annual Conference Abstracts (APIC '13), Ft. Lauderdale, Fla, USA, June 2013.

[44] A. Dobin, "Broward Health Coral Springs Medical Center: bloodstream infections eliminated by use of plastic cap for disinfecting needleless connectors," in Proceedings of the 38th Annual Association for Professionals in Infection Control and Epidemiology (APIC) Meeting, Baltimore, Md, USA, June 2011.

[45] D. G. Maki, M. Ringer, and C. J. Alvarado, "Prospective randomised trial of povidone-iodine, alcohol, and chlorhexidine for prevention of infection associated with central venous and arterial catheters," The Lancet, vol. 338, no. 8763, pp. 339-343, 1991.

[46] M. K. Muffly, M. L. Beach, Y. C. Isaac Tong, and M. P. Yeager, "Stopcock lumen contamination does not reflect the full burden of bacterial intravenous tubing contamination: analysis using a novel injection port," The American Journal of Infection Control, vol. 38, no. 9, pp. 734-739, 2010.
[47] M. A. Luebke, M. J. Arduino, D. L. Duda et al., "Comparison of the microbial barrier properties of a needleless and a conventional needle-based intravenous access system," American Journal of Infection Control, vol. 26, no. 4, pp. 437-441, 1998.

[48] M. DeVries, P. Mancos, and M. Valentine, "Improving catheter cleaning and maintenance in central and peripheral lines," in APIC Annual Conference, Ft. Lauderdale, Fla, USA, 2013.

[49] P. Posa, "Improving IV connector disinfection by using human factors engineering to identify effective, nurse-friendly solutions," in Proceedings of the APIC Annual Conference, Ft. Lauderdale, Fla, USA, 2014.

[50] M. Pittiruti, H. Hamilton, R. Biffi, J. MacFie, and M. Pertkiewicz, "ESPEN guidelines on parenteral nutrition: central venous catheters (access, care, diagnosis and therapy of complications)," Clinical Nutrition, vol. 28, no. 4, pp. 365-377, 2009.

[51] N. L. Moureau and R. B. Dawson, "Keeping needleless connectors clean, part 1," Nursing, vol. 40, no. 5, pp. 18-19, 2010.

[52] CDC, National Action Plan to Prevent Health Care-Associated Infections: Road Map to Eliminat, Centers for Disease Control and Prevention, Atlanta, Ga, USA, 2012.

[53] H. P. Loveday, J. A. Wilson, R. J. Pratt et al., "Epic3: National evidence-based guidelines for preventing healthcare-associated infections in nhs hospitals in England," Journal of Hospital Infection, vol. 86, supplement 1, pp. S1-S70, 2014.

[54] N. Moureau, "Safe patient care when using vascular access devices," British Journal of Nursing, vol. 22, no. 2, pp. S14-S21, 2013.

[55] D. K. Warren, J. E. Zack, J. L. Mayfield et al., "The effect of an education program on the incidence of central venous catheterassociated bloodstream infection in a medical ICU," Chest, vol. 126, no. 5, pp. 1612-1618, 2004.

[56] CDC, Safe Healthcare: Healthcare-Associated Infections, CDC Safe Healthcare Blog, 2013.

[57] A. Mian, C. Russell, M. Honeycutt, and C. Oldridge, "Multidisciplinary approach to reduction of central line associated blood stream infections (CLABSI): an institutional experience with collaborative guidelines," The Journal of the Arkansas Medical Society, vol. 109, no. 7, pp. 128-131, 2012.

[58] S. Rowley, S. Clare, S. MacQueen, and R. Molyneux, "ANTT v2: an updated practice framework for aseptic technique," British Journal of Nursing, vol. 19, no. 5, pp. S5-S11, 2010.

[59] S. Rowley and S. Clare, "Aseptic non touch technique (ANTT): reducing healthcare associated infections (HCAI) by standardising aseptic technique with ANTT across large clinical workforces," American Journal of Infection Control, vol. 39, no. 5, p. E90, 2011.

[60] N. Moureau, Winning the War on CLABSIs: The Role of Education and New Technology, ICT, 2009.

[61] Joint Commission, Accreditation Program: 2010 Hospital National Patient Safety Goals, 2010, edited by: Joint Commission.

[62] R. Dawson and N. Moureau, "Implementing new joint commission requirements using revised protocol to disinfect intravenous access ports/needleless connectors," in Proceedings of the 12th Annual NPSF Patient Safety Congress, Orlando, Fla, USA, 2010.

[63] INS, Policies and Procedures for Infusion Nursing, 4th edition, 2011.

[64] N. Moureau, "Catheter-associated bloodstream infection prevention: what is missing?" British Journal of Healthcare Management, vol. 20, no. 11, pp. 502-510, 2014. 
[65] G. D. Sacks, B. S. Diggs, P. Hadjizacharia, D. Green, A. Salim, and D. J. Malinoski, "Reducing the rate of catheter-associated bloodstream infections in a surgical intensive care unit using the Institute for Healthcare Improvement Central Line Bundle," The American Journal of Surgery, vol. 207, no. 6, pp. 817-823, 2014.

[66] R. D. Lobo, A. S. Levin, L. M. Brasileiro Gomes et al., "Impact of an educational program and policy changes on decreasing catheter-associated bloodstream infections in a medical intensive care unit in Brazil," American Journal of Infection Control, vol. 33, no. 2, pp. 83-87, 2005.

[67] D. K. Warren, S. E. Cosgrove, D. J. Diekema et al., "A multicenter intervention to prevent catheter-associated bloodstream infections," Infection Control and Hospital Epidemiology, vol. 27, no. 7, pp. 662-669, 2006.

[68] W. Zingg, A. Imhof, M. Maggiorini, R. Stocker, E. Keller, and C. Ruef, "Impact of a prevention strategy targeting hand hygiene and catheter care on the incidence of catheter-related bloodstream infections," Critical Care Medicine, vol. 37, no. 7, pp. 2167-2173, 2009.

[69] C. Chernecky, L. Casella, E. Jarvis, D. Macklin, and M. Rosenkoetter, "Nurses' knowledge of intravenous connectors," Journal of Research in Nursing, vol. 15, no. 5, pp. 405-415, 2010.

[70] J. C. Yébenes, M. Delgado, G. Sauca et al., "Efficacy of three different valve systems of needle-free closed connectors in avoiding access of microorganisms to endovascular catheters after incorrect handling," Critical Care Medicine, vol. 36, no. 9, pp. 2558-2561, 2008.

[71] J. Segreti, S. Garcia-Houchins, L. Gorski et al., "Consensus conference on prevention of central line-associated bloodstream infections: 2009," Journal of Infusion Nursing, vol. 34, no. 2, pp. 126-133, 2011.

[72] W. Zingg, A. Imhof, M. Maggiorini, R. Stocker, E. Keller, and C. Ruef, "Impact of a prevention strategy targeting hand hygiene and catheter care on the incidence of catheter-related bloodstream infections," Critical Care Medicine, vol. 37, no. 7, pp. 2167-2173, 2009.

[73] D. K. Warren, J. E. Zack, M. J. Cox, M. M. Cohen, and V. J. Fraser, "An educational intervention to prevent catheter-associated bloodstream infections in a nonteaching, community medical center," Critical Care Medicine, vol. 31, no. 7, pp. 1959-1963, 2003.

[74] C. M. Coopersmith, J. E. Zack, M. R. Ward et al., "The impact of bedside behavior on catheter-related bacteremia in the intensive care unit," Archives of Surgery, vol. 139, no. 2, pp. 131-136, 2004.

[75] A. Corona and F. Raimondi, "Prevention of nosocomial infection in the ICU setting," Minerva Anestesiologica, vol. 70, no. 5, pp. 329-337, 2004.

[76] K. Cooper, G. Frampton, P. Harris et al., "Are educational interventions to prevent catheter-related bloodstream infections in intensive care unit cost-effective?" Journal of Hospital Infection, vol. 86, no. 1, pp. 47-52, 2014.

[77] G. K. Frampton, P. Harris, K. Cooper et al., "Educational interventions for preventing vascular catheter bloodstream infections in critical care: evidence map, systematic review and economic evaluation," Health Technology Assessment, vol. 18, no. 15, pp. 1-365, 2014.

[78] A. S. McAlearney and J. L. Hefner, "Facilitating central lineassociated bloodstream infection prevention: a qualitative study comparing perspectives of infection control professionals and frontline staff," American Journal of Infection Control, vol. 42, no. 10, supplement, pp. S216-S222, 2014.
[79] D. Cozanitis and P. Mäkelä, "The infected peripheral intravenous catheter: a degree of ignorance, neglect and indifference," Acta Anaesthesiologica Belgica, vol. 59, no. 2, pp. 59-63, 2008.

[80] D. Macklin, C. Chernecky, K. Nugent, and J. L. Waller, "A collaborative approach to improving patient care associated with vascular access devices," Journal of Vascular Access Devices, vol. 8, no. 2, pp. 8-13, 2003.

[81] P. Ramritu, K. Halton, D. Cook, M. Whitby, and N. Graves, "Catheter-related bloodstream infections in intensive care units: a systematic review with meta-analysis," Journal of Advanced Nursing, vol. 62, no. 1, pp. 3-21, 2008.

[82] M. G. Cherry, J. M. Brown, T. Neal, and N. B. Shaw, "What features of educational interventions lead to competence in aseptic insertion and maintenance of $\mathrm{CV}$ catheters in acute care? BEME Guide No. 15," Medical Teacher, vol. 32, no. 3, pp. 198-218, 2010

[83] M. G. Cherry, J. M. Brown, G. S. Bethell, T. Neal, and N. J. Shaw, "Features of educational interventions that lead to compliance with hand hygiene in healthcare professionals within a hospital care setting. A BEME systematic review: BEME Guide No. 22," Medical Teacher, vol. 34, no. 6, pp. e406-e420, 2012.

[84] N. Arora, K. Patel, C. A. Engell, and J. A. LaRosa, "The effect of interdisciplinary team rounds on urinary catheter and central venous catheter days and rates of infection," The American Journal of Medical Quality, vol. 29, no. 4, pp. 329-334, 2013.

[85] K. R. Herzer, L. Niessen, D. O. Constenla, W. J. Ward, and P. J. Pronovost, "Cost-effectiveness of a quality improvement programme to reduce central line-associated bloodstream infections in intensive care units in the USA," British Medical Journal, vol. 4, no. 9, Article ID e006065, 2014.

[86] N. L. Moureau and R. B. Dawson, "Needleless connector knowhow," Nursing Management, vol. 41, no. 12, pp. 40-41, 2010.

[87] N. L. Moureau and R. B. Dawson, "Keeping needleless connectors clean. Part 2," Nursing, vol. 40, no. 6, pp. 61-62, 2010.

[88] L. Hadaway, "Intermittent intravenous administration sets: survey of current practices," Journal of the Association for Vascular Access, vol. 12, no. 3, pp. 143-147, 2007.

[89] B. M. Farr, "Reasons for noncompliance with infection control guidelines," Infection Control and Hospital Epidemiology, vol. 21, no. 6, pp. 411-416, 2000.

[90] D. Platace, I. Klava, L. Antonevica et al., "The study of the risk factors of health care-associated infections in patients' care with invasive devices," Acta Chirurgica Latviensis, vol. 9, no. 1, pp. 50-55, 2009.

[91] J. S. Smith, K. M. Kirksey, H. Becker, and A. Brown, "Autonomy and Self-efficacy as influencing factors in nurses' behavioral Intention to disinfect needleless intravenous systems," Journal of Infusion Nursing, vol. 34, no. 3, pp. 193-200, 2011.

[92] J. M. Jardim, R. A. Lacerda, N. D. J. D. Soares, and B. K. Nunes, "Evaluation of practices for the prevention and control of bloodstream infections in a government hospital," Revista da Escola de Enfermagem, vol. 47, no. 1, pp. 38-45, 2013.

[93] Y. J. Hsu, K. Weeks, T. Yang, M. D. Sawyer, and J. A. Marsteller, "Impact of self-reported guideline compliance: bloodstream infection prevention in a national collaborative," The American Journal of Infection Control, vol. 42, no. 10, supplement, pp. S191S196, 2014.

[94] D. K. Warren, D. S. Yokoe, M. W. Climo et al., "Preventing catheter-associated bloodstream infections: a survey of policies for insertion and care of central venous catheters from hospitals 
in the prevention epicenter program," Infection Control and Hospital Epidemiology, vol. 27, no. 1, pp. 8-13, 2006.

[95] K. Y. Blot, S. I. Blot, and D. Vandijck, "Implementation strategies for quality improvement interventions to prevent catheterrelated bloodstream infections," Critical Care Medicine, vol. 42, no. 5, article e382, 2014.

[96] K. Blot, J. Bergs, D. Vogelaers, S. Blot, and D. Vandijck, "Prevention of central line-associated bloodstream infections through quality improvement interventions: a systematic review and meta-analysis," Clinical Infectious Diseases, vol. 59, no. 1, pp. 96105, 2014.

[97] A. M. Fernandez, J. J. Schrogie, W. W. Wilson, and D. B. Nash, "Technology assessment in healthcare: a review and description of a 'best practice' technology assessment process," Best Practices and Benchmarking in Healthcare, vol. 2, no. 6, pp. 240-253, 1997.

[98] (NICE) NIfHaCE, Guide to the Methods of Technology Appraisal 2013, NICE, 2013, http://www.nice.org.uk/article/pmg9/chapter/ 1-introduction.

[99] M. Ryder, "Improve CRBSI prevention: target intraluminal risks," Executive Healthcare Management, no. 8, pp. 1-4, 2009.

[100] M. Ryder, Health-Care-Acquired Infections: Unfortunate Complication or Medical Error? Advocate, 2006.

[101] M. Ryder, "Evidence-based practice in the management of vascular access devices for home parenteral nutrition therapy," Journal of Parenteral and Enteral Nutrition, vol. 30, supplement 1, pp. S82-S93, 2006.

[102] National Health and Medical Research Council, NHMRC additional levels of evidence and grades for recommendations for developers of guidelines, Commonwealth of Australia, 2009, http://www.nhmrc.gov.au/_files_nhmrc/file/guidelines/developers/nhmrc_levels_grades_evidence_120423.pdf.

[103] J. G. DeVries and G. C. Berlet, "Understanding levels of evidence for scientific communication," Foot \& Ankle Specialist, vol. 3, no. 4, pp. 205-209, 2010.

[104] University of Newcastle, Evidence Pyramid, University of Newcastle, Callaghan, Australia, 2014, http://libguides.newcastle.edu .au/content.php? pid=259537\&sid=2147128.

[105] P. Pronovost, D. Needham, S. Berenholtz et al., "An intervention to decrease catheter-related bloodstream infections in the ICU: Keystone Project," The New England Journal of Medicine, vol. 355, no. 26, pp. 2725-2732, 2006.

[106] I. S. Jeong, S. M. Park, J. M. Lee, J. Y. Song, and S. J. Lee, "Effect of central line bundle on central line-associated bloodstream infections in intensive care units," American Journal of Infection Control, vol. 41, no. 8, pp. 710-716, 2013.

[107] B. L. Lobo, G. Vaidean, J. Broyles, A. B. Reaves, and R. I. Shorr, "Risk of venous thromboembolism in hospitalized patients with peripherally inserted central catheters," Journal of Hospital Medicine, vol. 4, no. 7, pp. 417-422, 2009.

[108] I. I. Raad, M. Luna, S.-A. M. Khalil, J. W. Costerton, C. Lam, and G. P. Bodey, "The relationship between the thrombotic and infectious complications of central venous catheters," The Journal of the American Medical Association, vol. 271, no. 13, pp. 1014-1016, 1994.

[109] J. Davis, "Central-line-associated bloodstream infection: comprehensive, data-driven prevention," Pennsylvania Patient Safety Authority, vol. 8, no. 3, pp. 100-104, 2011.

[110] L. A. Mermel, "What is the predominant source of intravascular catheter infections?" Clinical Infectious Diseases, vol. 52, no. 2, pp. 211-212, 2011.
[111] C. Chernecky, "Biofilm formation in connectors characterized by using electron microscopy," in Proceedings of the Association for Vascular Access Scientific Meeting, National Harbor, Md, USA, September 2014.

[112] M. A. Ryder, "Catheter-related infections: it's all about biofilm," Topics in Advanced Practice Nursing, vol. 5, no. 3, 2005.

[113] A. Sitges-Serra, P. Puig, J. Linares et al., "Hub colonization as the initial step in an outbreak of catheter-related sepsis due to coagulase negative staphylococci during parenteral nutrition," Journal of Parenteral and Enteral Nutrition, vol. 8, no. 6, pp. 668672, 1984.

[114] T. Karchmer, E. Cook, E. Palavecino, C. Ohl, and R. Sherertz, "Needleless valve ports may be associated with a high rate of catheter-related bloodstream infection [poster 307]," in Proceedings of the 15th Annual Scientific Meeting of the Society for Healthcare Epidemiology of America (Los Angeles), Society for Healthcare Epidemiology of America, Alexandria, Va, USA, 2005.

[115] J. Lee, "Disinfection cap makes critical difference in central line bundle for reducing CLABSIs," in Proceedings of the APIC Annual Conference, vol. 39, p. E64, Fort Lauderdale, Fla, USA, 2013.

[116] L. Hadaway, "Short peripheral intravenous catheters and infections," Journal of Infusion Nursing, vol. 35, no. 4, pp. 230-240, 2012.

[117] R. Carrico, Ed., APIC Text of Infection Control and Epidemiology, Association for Professional in Infection Control and Epidemiology, Washington, DC, USA, 2nd edition, 2005.

[118] Infusion Nurses Society, Policies and Procedures for Infusion Nursing, 2002.

[119] B. S. Niël-Weise, T. J. Daha, and P. J. van den Broek, "Is there evidence for recommending needleless closed catheter access systems in guidelines? A systematic review of randomized controlled trials," Journal of Hospital Infection, vol. 62, no. 4, pp. 406-413, 2006.

[120] V. D. Rosenthal and D. G. Maki, "Prospective study of the impact of open and closed infusion systems on rates of central venous catheter-associated bacteremia," The American Journal of Infection Control, vol. 32, no. 3, pp. 135-141, 2004.

[121] M. Ishizuka, H. Nagata, K. Takagi, and K. Kubota, "Needleless closed system does not reduce central venous catheter-related bloodstream infection: a retrospective study," International Surgery, vol. 98, no. 1, pp. 88-93, 2013.

[122] K. Field, C. McFarlane, A. C. Cheng et al., "Incidence of catheter-related bloodstream infection among patients with a needleless, mechanical valve-based intravenous connector in an Australian hematology-oncology unit," Infection Control and Hospital Epidemiology, vol. 28, no. 5, pp. 610-613, 2007.

[123] N. Safdar and D. G. Maki, "The pathogenesis of catheterrelated bloodstream infection with noncuffed short-term central venous catheters," Intensive Care Medicine, vol. 30, no. 1, pp. 62-67, 2004.

[124] L. C. Hadaway, "Skin Flora and Infection," Journal of Infusion Nursing, vol. 26, no. 1, pp. 44-48, 2003.

[125] D. G. Maki, C. E. Weise, and H. W. Sarafin, "A semiquantitative culture method for identifying intravenous catheter related infection," The New England Journal of Medicine, vol. 296, no. 23, pp. 1305-1309, 1977.

[126] D. G. Maki, S. M. Stolz, S. Wheeler, and L. A. Mermel, "Prevention of central venous catheter-related bloodstream infection by use of an antiseptic-impregnated catheter: a randomized, 
controlled trial," Annals of Internal Medicine, vol. 127, no. 4, pp. 257-266, 1997.

[127] A. Sitges-Serra, J. Linares, and J. Garau, "Catheter sepsis: the clue is the hub," Surgery, vol. 97, no. 3, pp. 355-357, 1985.

[128] M. L. Moro, E. F. Viganò, and A. C. Lepri, "Risk factors for central venous catheter-related infections in surgical and intensive care units. The Central Venous Catheter-Related Infections Study Group," Infection Control and Hospital Epidemiology, vol. 15, no. 4, part 1, pp. 253-264, 1994.

[129] B. Brismar, L. Jordahl, B. Nystrom, and N. Pettersson, "Bacterial contamination of intravenous line side ports of different designs," Clinical Nutrition, vol. 6, no. 1, pp. 31-33, 1987.

[130] V. M. Seymou, T. S. Dhallu, H. A. Mos, S. E. Tebb, and T. S. J. Elliot, "A prospective clinical study to investigate the microbial contamination of a needleless connector," Journal of Hospital Infection, vol. 45, no. 2, pp. 165-168, 2000.

[131] A. L. Casey, T. Worthington, P. A. Lambert, D. Quinn, M. H. Faroqui, and T. S. J. Elliott, "A randomized, prospective clinical trial to assess the potential infection risk associated with the PosiFlow needleless connector," Journal of Hospital Infection, vol. 54, no. 4, pp. 288-293, 2003.

[132] R. J. Sherertz, T. B. Karchmer, E. Palavecino, and W. Bischoff, "Blood drawn through valved catheter hub connectors carries a significant risk of contamination," European Journal of Clinical Microbiology and Infectious Diseases, vol. 30, no. 12, pp. 15711577, 2011.

[133] J. Liñares, A. Sitges-Serra, J. Garau, J. L. Pérez, and R. Martín, "Pathogenesis of catheter sepsis: a prospective study with quantitative and semiquantitative cultures of catheter hub and segments," Journal of Clinical Microbiology, vol. 21, no. 3, pp. 357-360, 1985.

[134] D. G. Maki, "Preventing infection in intravenous therapy," Anesthesia and Analgesia, vol. 56, no. 1, pp. 141-153, 1977.

[135] J. M. Walz, K. Faris, and S. O. Heard, "Who let the bugs in?" Critical Care Medicine, vol. 36, no. 9, pp. 2689-2690, 2008.

[136] J. C. Yébenes, R. Martinez, M. Serra-Prat et al., "Resistance to the migration of microorganisms of a needle-free disinfectable connector," The American Journal of Infection Control, vol. 31, no. 8, pp. 462-464, 2003.

[137] J. D. Brown, H. A. Moss, and T. S. J. Elliott, "The potential for catheter microbial contamination from a needleless connector," Journal of Hospital Infection, vol. 36, no. 3, pp. 181-189, 1997.

[138] B. W. Trautner and R. O. Darouiche, "Catheter-associated infections: pathogenesis affects prevention," Archives of Internal Medicine, vol. 164, no. 8, pp. 842-850, 2004.

[139] J.-C. Lucet, J. Hayon, F. Bruneel, J.-L. Dumoulin, and M.L. Joly-Guillou, "Microbiological evaluation of central venous catheter administration hubs," Infection Control and Hospital Epidemiology, vol. 21, no. 1, pp. 40-42, 2000.

[140] R. M. Donlan, "Biofilms and device-associated infections," Emerging Infectious Diseases, vol. 7, no. 2, pp. 277-281, 2001.

[141] R. M. Donlan and J. W. Costerton, "Biofilms: survival mechanisms of clinically relevant microorganisms," Clinical Microbiology Reviews, vol. 15, no. 2, pp. 167-193, 2002.

[142] R. Donlan, "Biofilms on central venous catheters: is eradication possible?" in Bacterial Biofilms, vol. 322 of Current Topics in Microbiology and Immunology, pp. 133-161, Springer, Berlin, Germany, 2008.

[143] M. Ryder, G. Hamilton, M. Hamilton, and G. James, "Bacterial transfer through needlefree connectors: comparison of nine different devices," in Proceedings of the Society for Healthcare
Epidemiology of America Annual Scientific Meeting, Baltimore, Md, USA, 2007.

[144] A. Sitges-Serra, J. Linares, J. L. Perez, E. Jaurrieta, and L. Lorente, "A randomized trial on the effect of tubing changes on Hub contamination and catheter sepsis during parenteral nutrition," Journal of Parenteral and Enteral Nutrition, vol. 9, no. 3, pp. 322325, 1985.

[145] C. León, F. Álvarez-Lerma, S. Ruiz-Santana et al., "Antiseptic chamber-containing hub reduces central venous catheterrelated infection: a prospective, randomized study," Critical Care Medicine, vol. 31, no. 5, pp. 1318-1324, 2003.

[146] M. Leone and L. R. Dillon, "Catheter outcomes in home infusion,” Journal of Infusion Nursing, vol. 31, no. 2, pp. 84-91, 2008.

[147] I. Raad, W. Costerton, U. Sabharwal, M. Sacilowski, E. Anaissie, and G. P. Bodey, "Ultrastructural analysis of indwelling vascular catheters: a quantitative relationship between luminal colonization and duration of placement," Journal of Infectious Diseases, vol. 168, no. 2, pp. 400-407, 1993.

[148] E. Perez, M. Williams, J. T. Jacob et al., "Microbial biofilms on needleless connectors for central venous catheters: comparison of standard and silver-coated devices collected from patients in an acute care hospital," Journal of Clinical Microbiology, vol. 52, no. 3, pp. 823-831, 2014.

[149] R. W. Loftus, H. M. Patel, B. C. Huysman et al., "Prevention of intravenous bacterial injection from health care provider hands: the importance of catheter design and handling," Anesthesia and Analgesia, vol. 115, no. 5, pp. 1109-1119, 2012.

[150] D. Macklin, "Catheter management," Seminars in Oncology Nursing, vol. 26, no. 2, pp. 113-120, 2010.

[151] J. L. Holroyd, D. A. Paulus, K. H. Rand, F. K. Enneking, T. E. Morey, and M. J. Rice, "Universal intravenous access cleaning device fails to sterilize stopcocks," Anesthesia and Analgesia, vol. 118, no. 2, pp. 333-343, 2014.

[152] D. G. Maki, "In vitro studies of a novel antimicrobial lueractivated needleless connector for prevention of catheterrelated bloodstream infection," Clinical Infectious Diseases, vol. 50, no. 12, pp. 1580-1587, 2010.

[153] R. Orenstein, "The benefits and limitations of needle protectors and needleless intravenous systems," Journal of Intravenous Nursing, vol. 22, no. 3, pp. 122-128, 1999.

[154] W. Jarvis, "Needleless connectors and the improvement of patient and healthcare professional safety," Infection Control Today, vol. 17, no. 12, 2013.

[155] ECRI Institute, "Evaluation: needleless connectors," Health Devices, vol. 37, no. 9, pp. 261-281, 2008.

[156] L. Hadaway, "Hub disinfection and its impact on Catheterrelated infections," Journal of Vascular Access Devices, vol. 6, no. 2, pp. 33-36, 2001.

[157] C. Chernecky, D. Macklin, L. Casella, and E. Jarvis, "Caring for patients with cancer through nursing knowledge of IV connectors," Clinical Journal of Oncology Nursing, vol. 13, no. 6, pp. 630-633, 2009.

[158] C. D. Salgado, L. Chinnes, T. H. Paczesny, and J. R. Cantey, "Increased rate of catheter-related bloodstream infection associated with use of a needleless mechanical valve device at a long-term acute care hospital," Infection Control and Hospital Epidemiology, vol. 28, no. 6, pp. 684-688, 2007.

[159] J. L. Lockman, E. S. Heitmiller, J. A. Ascenzi, and I. Berkowitz, "Scrub the Hub! catheter needleless port decontamination," Anesthesiology, vol. 114, no. 4, article 958, 2011. 
[160] Y. P. Tabak, W. R. Jarvis, X. Sun, C. T. Crosby, and R. S. Johannes, "Meta-analysis on central line-associated bloodstream infections associated with a needleless intravenous connector with a new engineering design," American Journal of Infection Control, vol. 42, no. 12, pp. 1278-1284, 2014.

[161] N. Khalidi, D. S. Kovacevich, L. F. Papke-O’Donnell, and I. Btaiche, "Impact of the positive pressure valve on vascular access device occlusions and bloodstream infections," The Journal of the Association for Vascular Access, vol. 14, no. 2, pp. 84-91, 2009.

[162] S. Schilling, D. Doellman, N. Hutchinson, and B. R. Jacobs, “The impact of needleless connector device design on central venous catheter occlusion in children: a prospective, controlled trial," Journal of Parenteral and Enteral Nutrition, vol. 30, no. 2, pp. 85-90, 2006.

[163] J. Luna, G. Masdeu, M. Pérez et al., "Clinical trial evaluating a new hub device designed to prevent catheter-related sepsis," European Journal of Clinical Microbiology and Infectious Diseases, vol. 19, no. 9, pp. 655-662, 2000.

[164] L. C. Hadaway, "Evaluation and use of advanced I.V. technology. Part 2: patient controlled analgesia," Journal of Intravenous Nursing, vol. 12, no. 3, pp. 184-191, 1989.

[165] D. D. McMahon, "Evaluating new technology to improve patient outcomes: a quality improvement approach," Journal of Infusion Nursing, vol. 25, no. 4, pp. 250-255, 2002.

[166] S. Cicalini, F. Palmieri, and N. Petrosillo, "Clinical review: new technologies for prevention of intravascular catheter-related infections," Critical Care, vol. 8, no. 3, pp. 157-162, 2004.

[167] S. T. Cookson, M. Ihrig, E. M. O’Mara et al., "Increased bloodstream infection rates in surgical patients associated with variation from recommended use and care following implementation of a needleless device," Infection Control and Hospital Epidemiology, vol. 19, no. 1, pp. 23-27, 1998.

[168] J. S. Soothill, K. Bravery, A. Ho, S. Macqueen, J. Collins, and P. Lock, "A fall in bloodstream infections followed a change to $2 \%$ chlorhexidine in $70 \%$ isopropanol for catheter connection antisepsis: a pediatric single center before/after study on a hemopoietic stem cell transplant ward," The American Journal of Infection Control, vol. 37, no. 8, pp. 626-630, 2009.

[169] S. Sannoh, B. Clones, J. Munoz, M. Montecalvo, and B. Parvez, "A multimodal approach to central venous catheter hub care can decrease catheter-related bloodstream infection," American Journal of Infection Control, vol. 38, no. 6, pp. 424-429, 2010.

[170] J. S. Smith, G. Irwin, M. Viney et al., "Optimal disinfection times for needleless intravenous connectors," The Journal of the Association for Vascular Access, vol. 17, no. 3, pp. 137-143, 2012.

[171] M. E. Rupp, S. Yu, T. Huerta et al., "Adequate disinfection of a split-septum needleless intravascular connector with a 5second alcohol scrub," Infection Control and Hospital Epidemiology, vol. 33, no. 7, pp. 661-665, 2012.

[172] J. H. Macias, V. Arreguin, J. M. Munoz, J. A. Alvarez, J. L. Mosqueda, and A. E. Macias, "Chlorhexidine is a better antiseptic than povidone iodine and sodium hypochlorite because of its substantive effect," The American Journal of Infection Control, vol. 41, no. 7, pp. 634-637, 2013.

[173] K. L. Ruschman and J. S. Fulton, "Effectiveness of disinfectant techniques on intravenous tubing latex injection ports," Journal of Intravenous Nursing, vol. 16, no. 5, pp. 304-308, 1993.

[174] J. S. Garland, R. K. Buck, P. Maloney et al., "Comparison of $10 \%$ povidone-iodine and $0.5 \%$ chlorhexidine gluconate for the prevention of peripheral intravenous catheter colonization in neonates: a prospective trial," Pediatric Infectious Disease Journal, vol. 14, no. 6, pp. 510-516, 1995.

[175] E. M. Young, M. L. Commiskey, and S. J. Wilson, “Translating evidence into practice to prevent central venous catheterassociated bloodstream infections: a systems-based intervention," American Journal of Infection Control, vol. 34, no. 8, pp. 503-506, 2006.

[176] W. Kaler and R. Chinn, "Successful disinfection of needleless access ports: a matter of time and friction," The Journal of the Association for Vascular Access, vol. 12, no. 3, pp. 140-142, 2007.

[177] K. Guerin, J. Wagner, K. Rains, and M. Bessesen, "Reduction in central line-associated bloodstream infections by implementation of a postinsertion care bundle," The American Journal of Infection Control, vol. 38, no. 6, pp. 430-433, 2010.

[178] A. L. Buchman, J. Spapperi, and P. Leopold, "A new central venous catheter cap: decreased microbial growth and risk for catheter-related bloodstream infection," Journal of Vascular Access, vol. 10, no. 1, pp. 11-21, 2009.

[179] H. Hong, D. F. Morrow, T. J. Sandora, and G. P. Priebe, "Disinfection of needleless connectors with chlorhexidine-alcohol provides long-lasting residual disinfectant activity," American Journal of Infection Control, vol. 41, no. 8, pp. e77-e79, 2013.

[180] M. A. Mazher, A. Kallen, J. R. Edwards, and R. M. Donlan, "An In Vitro evaluation of disinfection protocols used for needleless connectors of central venous catheters," Letters in Applied Microbiology, vol. 57, no. 4, pp. 282-287, 2013.

[181] W. Kaler and R. Chinn, "Successful disinfection of needleless access ports: a matter of time and friction," Journal of the Association for Vascular Access, vol. 12, no. 3, pp. 140-147, 2007.

[182] F. Esteve, M. Pujol, E. Limón et al., "Bloodstream infection related to catheter connections: a prospective trial of two connection systems," Journal of Hospital Infection, vol. 67, no. 1, pp. 30-34, 2007.

[183] N. Moureau and R. Dawson, "Passive disinfection product effectiveness study," Infection Control and Hospital Epidemiology, vol. 28, no. 5, pp. 610-613, 2007.

[184] C. Stango, D. Runyan, J. Stern, I. Macri, and M. Vacca, "A successful approach to reducing bloodstream infections based on a disinfection device for intravenous needleless connector hubs," Journal of Infusion Nursing, vol. 37, no. 6, pp. 462-465, 2014.

[185] J. Oto, H. Imanaka, M. Konno, E. Nakataki, and M. Nishimura, "A prospective clinical trial on prevention of catheter contamination using the hub protection cap for needleless injection device," American Journal of Infection Control, vol. 39, no. 4, pp. 309-313, 2011.

[186] B. Lopansri, I. Nicolescu, A. Tomich, J. Belmares, and P. Schreckenberger, "Microbial colonization of needleless intravenous connectors and the male luer end of IV administration sets: does the partner matter?" in Proceedings of the 2011 SHEA Annual Scientific Meeting, April 2011.

[187] P. Posa and G. Siedlaczek, "Improving IV connector disinfection by using human factors engineering to identify effective, nursefriendly solutions," American Journal of Infection Control, vol. 41, no. 6, supplement, p. S22, 2013.

[188] R. Seiler and S. Meyer, "Improving infection control compliance using combined cap/flush syringe technology to reduce central line associated bloodstream infections," in Proceedings of the AVA Annual Scientific Meeting, Nashville, Tenn, USA, 2013.

[189] M. Davis, Forcing the Function: Implementation and Evaluation of an IV Port Protector to Decrease CLABSI, National Teaching Institute \& Critical Care Exposition, Portland, Ore, USA, 2013. 
[190] F. Alasmari, N. Kittur, A. Russo et al., Impact of Alcohol Impregnated Protectors on Incidence of Catheter-Associated Blood Stream Infections, Infectious Diseases Society of America, 2012.

[191] A. Pong, C. Salgado, M. Speziale, P. Grimm, and C. Abe, "Rady children's hospital san diego: reduction of central line associated bloodstream infection (CLABSI) in a neonatal intensive care unit with use of access site disinfection caps," in Proceedings of the 2011 IDSA Annual Meeting, Boston, Mass, USA, 2011.

[192] J. Shiber, G. Jolicoeur, and T. Crouchet, "Ochsner medical center: reducing central line-associated bloodstream infections through the addition of disinfecting port protector caps to the central line bundle," in Proceedings of the Annual Research Day, New Orleans, La, USA, May 2014.

[193] K. C. Merrill, S. Sumner, L. Linford, C. Taylor, and C. Macintosh, "Impact of universal disinfectant cap implementation on central line-associated bloodstream infections," American Journal of Infection Control, vol. 42, no. 12, pp. 1274-1277, 2014.

[194] M. Leone and M. Pratt, "Preventing central line-associated bloodstream infections in home infusion patients through the use of disinfection caps," Infusion, vol. 17, no. 6, pp. 10-14, 2011.

[195] B. Caillouet, "Protection of intraluminal pathway with zero fluid displacement connector reduces catheter-related bloodstream infections in a comprehensive cancer center," The Journal of the Association for Vascular Access, vol. 17, no. 2, pp. 86-89, 2012.

[196] Joint Commission, National Patient Safety Goal: NPSG 07.04.01, The Joint Commission Accreditation Program: Hospital, 2011.

[197] C. M. Rickard, J. Webster, and E. G. Playford, "Prevention of peripheral intravenous catheter-related bloodstream infections: the need for a new focus," Medical Journal of Australia, vol. 198, no. 10, pp. 519-520, 2013.

[198] C. L. Boyer and D. C. Wade, "The impact of compliance on quality outcomes in the home infusion population," Journal of Intravenous Nursing, vol. 21, no. 5, pp. S161-S165, 1998.

[199] M. McGuckin, R. Waterman, L. Porten et al., "Patient education model for increasing handwashing compliance," The American Journal of Infection Control, vol. 27, no. 4, pp. 309-314, 1999.

[200] K. G. Sterba, "Controversial issues in the care and maintenance of vascular access devices in the long-term/subacute care client," Journal of Intravenous Nursing, vol. 24, no. 4, pp. 249-254, 2001.

[201] A. R. Burrell, M.-L. McLaws, M. Murgo, E. Calabria, A. C. Pantle, and R. Herkes, "Aseptic insertion of central venous lines to reduce bacteraemia: the central line associated bacteraemia in NSW intensive care units (CLAB ICU) collaborative," Medical Journal of Australia, vol. 194, no. 11, pp. 583-587, 2011.

[202] M. G. Fakih, K. Jones, J. E. Rey et al., "Sustained improvements in peripheral venous catheter care in non-intensive care units: a quasi-experimental controlled study of education and feedback," Infection Control and Hospital Epidemiology, vol. 33, no. 5, pp. 449-455, 2012.

[203] P. Rangachari, "Effective communication network structures for hospital infection prevention: a study protocol," Quality Management in Health Care, vol. 22, no. 1, pp. 16-24, 2013.

[204] L. C. Hadaway, "CE Best-practice interventions: keeping central line infection at bay," Nursing, vol. 36, no. 4, pp. 58-63, 2006.

[205] L. Hadaway, "Bacterial infection: awareness and prevention," Nursing Management, vol. 39, no. 10, p. 17, 2008. 


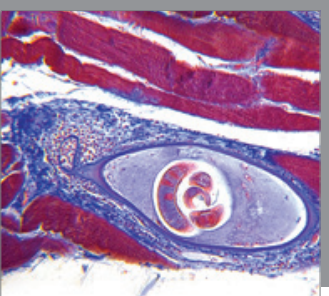

Gastroenterology

Research and Practice
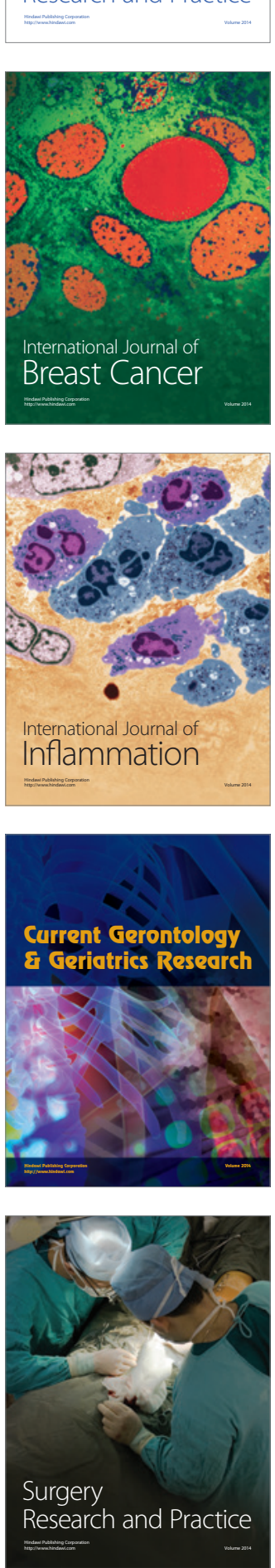

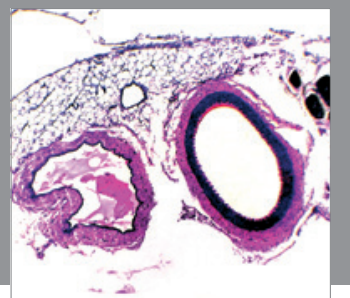

International Journal of Hypertension
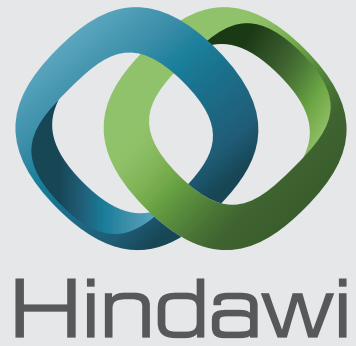

Submit your manuscripts at http://www.hindawi.com
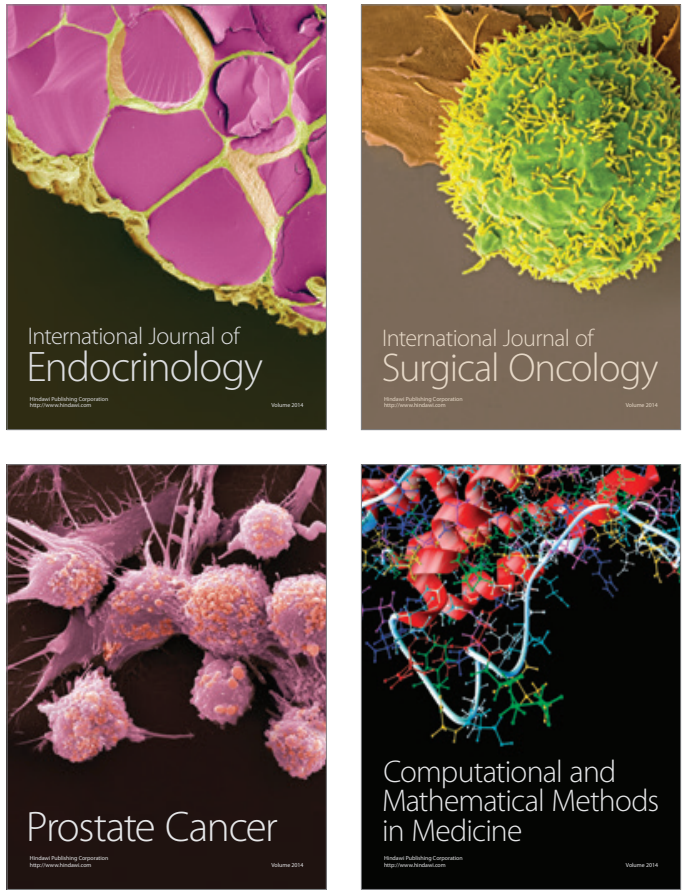
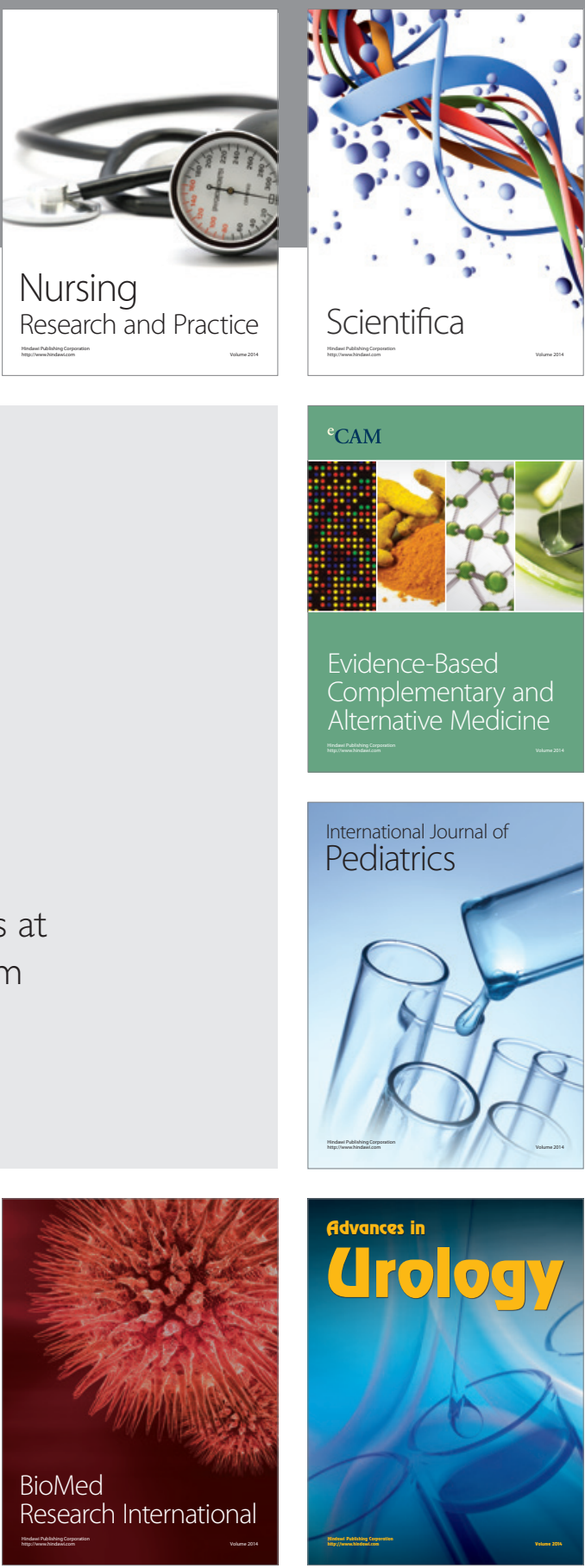

Nursing

Research and Practice

Scientifica

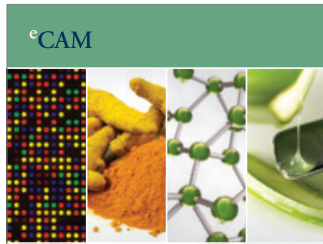

Evidence-Based

Complementary and Alternative Medicine
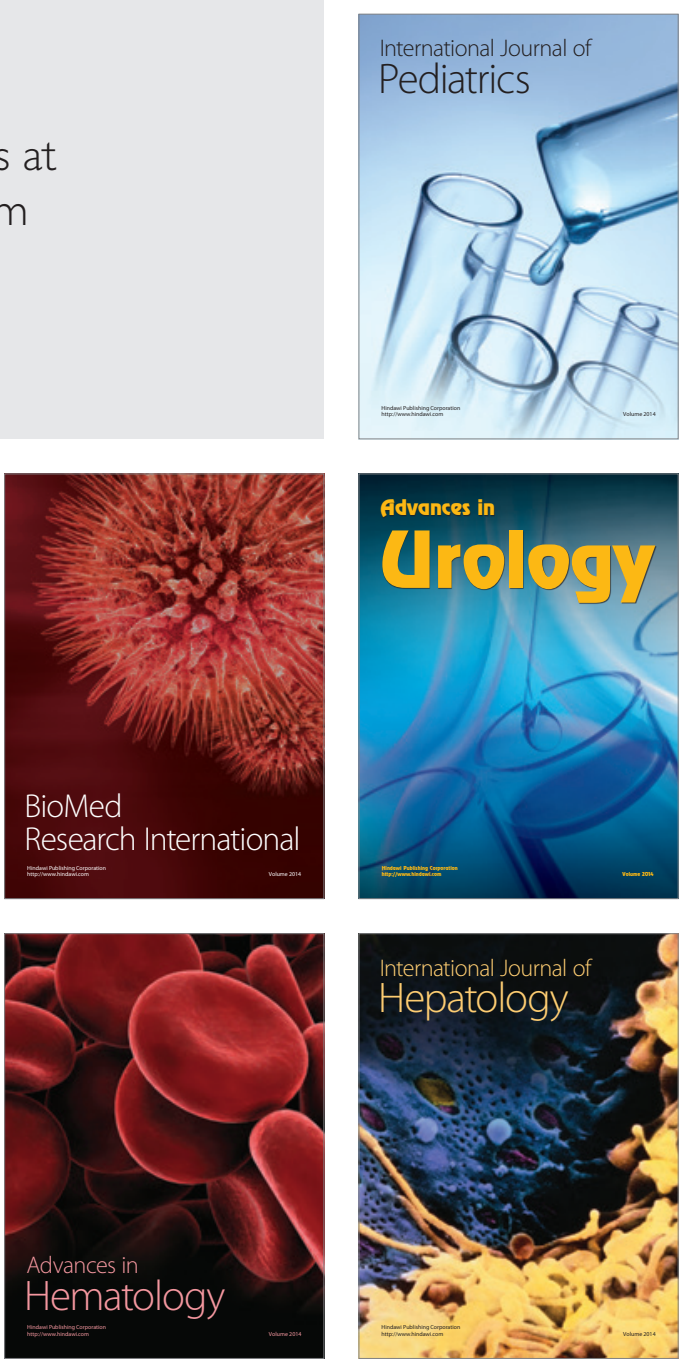